\title{
PETROGRAPHY AND PHASE EQUILIBRIA MODELING OF MID- P ALUMINOUS GNEISSES DERIVED FROM HYDROTHERMALLY ALTERED PROTOLITHS, GRENVILLE PROVINCE, CANADA
}

\begin{tabular}{|r|l|}
\hline Journal: & Canadian Journal of Earth Sciences \\
\hline Manuscript ID & cjes-2016-0162.R1 \\
\hline Manuscript Type: & Article \\
\hline Date Submitted by the Author: & $25-$ May-2017 \\
\hline $\begin{array}{r}\text { Complete List of Authors: } \\
\text { Is the invited manuscript for } \\
\text { consideration in a Special } \\
\text { Issue? : }\end{array}$ & $\begin{array}{l}\text { Patrick, Mackenzie; Memorial University of Newfoundland, Earth Sciences } \\
\text { Indares, Aphrodite; Dept of Earth Sciences }\end{array}$ \\
\hline Keyword: & $\begin{array}{l}\text { Phase equilibria modeling, Grenville Province, Partial melting, Aluminous } \\
\text { rocks }\end{array}$ \\
\hline
\end{tabular}




\title{
PETROGRAPHY AND PHASE EQUILIBRIA MODELING OF MID- $P$ ALUMINOUS GNEISSES DERIVED FROM HYDROTHERMALLY ALTERED PROTOLITHS, GRENVILLE PROVINCE, CANADA
}

\author{
Mackenzie Patrick, Aphrodite Indares \\ Department of Earth Sciences, Memorial University of Newfoundland \\ 300 Prince Phillip Dr., A1B 3X5, St John's, NL, Canada \\ *Corresponding Author: Mackenzie Patrick (Tel: 709-746-7311; email: n99mep@mun.ca)
}


PETROGRAPHY AND PHASE EQUILIBRIA MODELING OF MID$P$ ALUMINOUS GNEISSES DERIVED FROM HYDROTHERMALLY ALTERED PROTOLITHS, GRENVILLE

PROVINCE, CANADA

\section{Mackenzie Patrick, Aphrodite Indares}

\section{Abstract}

(1)

A large portion of the hinterland of the central Grenville Province is characterized by mid-pressure granulite-facies metamorphic rocks. In the Manicouagan - Lac du Milieu region of Quebec, aluminous gneisses derived from hydrothermally altered felsic protoliths provide a record of anatectic processes and of the pressure-temperature $(P-T)$ evolution during orogenesis. Samples collected in areas separated by several tens of kilometers consist of garnet + biotite + quartz + K-feldspar \pm plagioclase \pm sillimanite, with retrograde cordierite in some, and most display microstructural evidence of partial melting. However, they have a wide range of bulk compositions and textures, and may be grouped in two types: sillimanite-rich rocks, with a high alumina index in AFM space and sillimanite-poor rocks with low alumina index and in which sillimanite is not part of the peak assemblage.

Phase equilibria modeling with Thermocalc constrained the $P-T$ field of the peak mineral assemblage(s) at $800-900^{\circ} \mathrm{C}$ and 6-11 kbar, with melt solidification in the range 
22 of $800-865^{\circ} \mathrm{C}$ and $6-8 \mathrm{kbar}$. The presence of sillimanite inclusions in garnet, and the 23 scarcity of retrograde cordierite are consistent with moderate $\mathrm{d} P / \mathrm{d} T$ gradient 'hairpin' $P$

$24 T$ paths. The data suggest that this part of the mid- $P$ hinterland in the central Grenville

25 experienced a rather uniform high-temperature metamorphic evolution, with large

26 temperature variations relative to pressure. This is consistent with the thermal evolution

27 of middle crust beneath an orogenic plateau.

28 Key words: Phase Equilibria Modeling; Aluminous rocks; Grenville Province; Partial 29 melting; Pseudosection.

\section{$31 \quad$ Introduction}

High-temperature metamorphic processes play a major role in the tectonic

33 evolution of continental crust in mountain belts, and most particularly in "large hot

34 orogens" (Beaumont et al., 2006) where the middle to lower crust experiences partial

35 melting, melt transfer and ductile rheology (Brown, 2007). Formerly deep crust is widely

36 exposed in ancient orogens by late tectonism and erosion. A prime example of such an

37 orogen is the Grenville Province, which was active between 1.09 and 0.98 billion years

38 ago (Rivers et al, 2012; Rivers, 2008) along the eastern part of North America. Large

39 portions of the hinterland of the central Grenville Province reached mid-pressure

40 granulite-facies metamorphic conditions, and constitute prime material for the

41 investigation of high temperature metamorphic processes in deep orogenic crust. 
Aluminous rocks are particularly useful for metamorphic studies involving

43 anatexis because in addition to their mineral assemblages being sensitive to changes in

44 pressure $(P)$ and temperature $(T)$, they are also the most fertile with respect to melting

45 due to the presence of micas (Spear et al., 1999). Most studies of aluminous systems in

46 the literature have focused on metasedimentary rocks (e.g. metapelites and

47 metagreywakes). However, aluminous bulk chemistries may also be derived from

48 hydrothermal alteration of a wide range of felsic to mafic protoliths (Bonnet and

49 Corriveau, 2007), in which case they may be display significantly different features

50 relative to typical metasedimentary rocks (Lasalle and Indares, 2014).

51 The aim of this contribution is to investigate phase relations, melt productivity

52 and $P-T$ paths recorded by gneisses that have acquired (to some extent) their aluminous

53 character by pre-metamorphic hydrothermal alteration of felsic protoliths and display a

54 wide range of chemical compositions and microstructures. This paper builds on

55 Hindemith et al. (2017) who focuses on the origin of these rocks, and discussed in detail

56 the evidence regarding the hydrothermally altered nature of samples from most of these

57 localities. The rocks come from three locations separated by several 10s of kilometers in

58 the hinterland of the central Grenville Province, and the new $P-T$ data provide constrains

59 on the thermal evolution of this part of the orogen. The general approach used involves

60 documentation of microstructures, mineral chemistry and phase equilibria modeling.

62 Geological context 
64 The Grenville Province mainly consists of accreted arc terranes developed along

65 the southeast margin of proto-Laurentia between 1700 and $1230 \mathrm{Ma}$ (Gower and Krogh,

66 2002; Rivers and Corrigan, 2000) that were subjected to a continental collision between

671090 and $980 \mathrm{Ma}$ (Grenvillian Orogeny; see review in Rivers, 2008). Large parts of the

68 orogenic hinterland were metamorphosed under mid- $P$ (and locally high- $P$ ) granulite-

69 facies conditions during the Ottawan phase of the Grenvillian Orogeny (1090-1020 Ma),

70 resulting in partial melting and high crustal ductility, and constitute a key argument for

71 the development of an orogenic plateau (Rivers, 2008). These parts are juxtaposed with

72 domains that experienced lower grades of metamorphism (low- $P$ segment and Orogenic

73 Lid; Rivers, 2012), in a configuration that is interpreted to be the result of orogenic

74 collapse during the late-Ottawan (Rivers, 2012). The aluminous rocks of this study come

75 from the Manicouagan and Lac du Milieu areas of the mid- $P$ hinterland in the central

76 Grenville Province (Fig. 1).

77

78 The Manicouagan and Lac du Milieu areas

79 The mid- $P$ hinterland south of Manicouagan (Fig. 1) has been described by

80 Dunning and Indares (2010) and Indares and Moukhsil (2013), whereas its eastern

81 extension in the Lac du Milieu area was documented by Moukhsil et al. (2012). The two

82 areas display a wide variety of pre-Grenvillian plutonic and supracrustal rocks ranging in

83 age from $\sim 1.7 \mathrm{Ga}$ to $\sim 1.2 \mathrm{Ga}$, as well as Grenvillian age granite and anorthosite. The 
84 main lithologic associations of interest for this study are the Complexe de la Plus-Value 85 (PLV), and the layered bimodal suite (LBS).

The PLV is a metasedimentary sequence that extends from the Lac du Milieu area

87 to the southern Canyon domain, south of the Manicouagan reservoir (Fig. 1). It is made

88 up of quartzofeldspathic gneiss, metapelite, quartzite with minor marble and calcsilicate

89 rocks, and is inferred to have been deposited at $\sim 1.5 \mathrm{Ga}$ on the margin of Laurentia

90 (Moukhsil et al, 2012; Lasalle et al, 2013). Locally, the PLV in the Lac du Milieu area

91 (PLV-LM) contains an association of rusty-weathering aluminous gneiss - fine-grained

92 quartz-rich rocks with aluminous minerals. This association is interpreted to be derived

93 from pre-metamorphic hydrothermal alteration of the paragneisses but the exact

94 protoliths are unknown (Indares and Letourneau, in press).

95 The LBS, exposed in the central part of the Canyon domain (southern

96 Manicouagan; Fig. 1), is made up of mafic and felsic layers, inferred to represent

97 remnants of a volcanic belt emplaced in an extensional crustal setting (Indares and

98 Moukhsil, 2013), at 1238 \pm 13 Ma (Lasalle et al., 2013). Some felsic layers are white

99 gneisses of andesitic composition that locally grade into aluminous varieties and

100 garnetite, inferred to represent hydrothermally altered felsic volcanic rocks, mainly by

101 addition of $\mathrm{Fe}+\mathrm{Mg} \pm \mathrm{Mn}$ (Hindemith et al., 2017).

102 In addition, an association of aluminous rocks - fine-grained quartz-rich rocks

103 with aluminous minerals - white felsic gneiss is also exposed amongst tonalitic

104 migmatites of the Gabriel complex, on the Gabriel Islands (eastern Manicouagan

105 reservoir; Indares and Dunning, 2004; Strowbridge, 2006; Hindemith et al., 2017; Fig. 1). 
106 However, the age of the Gabriel Complex is unknown, and the affiliation of this

107 association, which will be referred to here as the Gabriel aluminous gneisses (GAG), is 108 uncertain.

109 Mid- $P$ granulite facies metamorphism in the Manicouagan and Lac du Milieu 110 areas is manifested by the presence of orthopyroxene \pm leucosome (quartz and feldspars)

111 in mafic rocks, and garnet + sillimanite + biotite + K-feldspar + plagioclase \pm leucosome

112 (quartz and feldspars) in aluminous rocks. At the outcrop scale, leucosomes are abundant

113 in the metapelites of the PLV, which have a marked migmatitic character, but they are

114 less obvious in the other aluminous gneisses. The age of metamorphism is constrained

115 between 1080 and 1040 Ma based on monazite and zircon data from the Manicouagan

116 area (Dunning and Indares, 2010; Lasalle et al., 2014). The only modern published

117 metamorphic study of aluminous rocks in this area was done by Lasalle and Indares

118 (2014), who used phase equilibria modeling to investigate the $P-T$ evolution of

119 metapelites of the PLV and some hydrothermally altered felsic rocks of the LBS.

120 However, it was not successful in retrieving $P-T$ paths for the hydrothermally altered

121 rocks. This contribution focuses on aluminous gneisses from the PLV-LM (aluminous

122 and quartz-rich rock association), the LBS in the Canyon domain, and the GAG.

\section{Petrography}

125 The samples from all three locations have the mineral assemblage of garnet +

126 biotite + quartz + K-feldspar \pm sillimanite \pm plagioclase with a wide range of textures and

127 mineral proportions. In addition, cordierite is present in the PLV-LM and in some of the 
128 GAG samples. The general distribution of phases was imaged by means of false color

129 mineral maps of polished thin sections (Fig. 2). These maps were acquired with a FEI

130 Quanta 600 scanning electron microscope (SEM) and JKTech Mineral Liberation

131 Analysis (MLA) software at the Bruneau Center, Memorial University of Newfoundland.

132 Analytical conditions included accelerating voltage of $25 \mathrm{kV}$, a $10 \mathrm{nA}$ beam current, and

133 a dwell time of $10 \mathrm{~ms}$. This method also produced mineral proportions, listed in Table 1.

134 Detailed key microstructures observed by optical microscopy are shown in Fig. 3.

135 In terms of the proportion and mode of occurrence of aluminosilicate, the samples

136 can be classified as: (a) sillimanite-rich, where sillimanite is part of the main assemblage,

137 and occurs in the matrix and in large proportions relative to the total aluminous minerals;

138 (Table 1; Figs. 2a-c, f, h) and (b) sillimanite-poor, where sillimanite is restricted within

139 aluminous nodules, inclusions in garnet, or absent altogether (Table 1; Figs. 2d, e, g). In

140 addition, two of the samples are quartz rich, and these are the most fine-grained (Figs. 2c, $141 \mathrm{~h})$.

142

\section{Samples from the PLV-LM}

144 The samples from the PLV-LM belong to the sillimanite-rich group, but the ratio 145 of quartzofeldspathic to aluminous minerals (Table 1), and their microstructures are 146 varied. Sample 10-AI-20a consists of diffuse layers rich in sillimanite, biotite and 147 elongated clusters of framboidal garnet, in a quartzofeldspathic matrix (Fig. 2a). Sample 148 10-AI-58-3b1 is mostly made of interwoven sillimanite+biotite, contains elongate garnet 149 porphyroblasts and has scarce quartz and feldspars, mainly concentrated in a boudinaged 
150 layer (vein?) (Fig. 2b). Finally, sample 10-AI-58-2A is quartz rich and fine-grained,

151 shows an even distribution of the aluminous minerals in the matrix and contains a quartz

152 vein with rafts of feldspars (Fig. 2c). We note that the later 2 samples represent distinct

153 aluminum-rich and quartz-rich layers of the same outcrop.

154 All samples exhibit strong foliation defined by the aluminous minerals. Garnet

155 porphyroblasts and clusters contain inclusions of acicular sillimanite, biotite, quartz and

156 feldspar, or polyminerallic inclusions of quartz, sillimanite and biotite rimmed by

157 feldspar (Fig. 3a). In addition, garnet is also corroded by biotite + sillimanite \pm

158 plagioclase, or cordierite (Fig. 2a). Sillimanite in the matrix is prismatic, and biotite

159 commonly forms symplectites with quartz, and locally feldspars, in the vicinity of garnet

160 (Fig. 3b). Cordierite occurs as elongated interstitial patches (Figs. 2b, c, 3c) which

161 replace sillimanite and garnet (Fig. 3d). Plagioclase is minor, and in 10-AI-58-3B1 it is

162 restricted to sites of garnet replacement, and around K-feldspar.

\section{Samples from the LBS}

165 The selected two samples from the LBS belong to the sillimanite-poor group and 166 lack cordierite (Table 1). In 331-e2-11, the aluminous minerals are mostly concentrated

167 in elongate clusters, which define the foliation. Sillimanite is restricted to these clusters,

168 where it is overgrown by garnet. Garnet is porphyroblastic and contains both

169 monomineralic (quartz, sillimanite, biotite) and polyminerallic inclusions where biotite

170 and rounded quartz grains are surrounded by thin films of feldspars (Figs. 3e, f). Garnet

171 rims are partly replaced by biotite, which locally forms symplectites with quartz. The 
172 matrix is rich in K- feldspar, with plagioclase mainly concentrated at the rims of the

173 aluminous clusters. Quartz occurs as scattered and resorbed domains, some of which have

174 angular shape and were interpreted by Hindemith et al. (2017) as relict xenocrysts.

175 Sample 216a consists of a garnet-bearing layered quartzofeldspathic matrix, and

176 has very small amounts of biotite and sillimanite. Garnet has a wide range of sizes and

177 shapes, and some porphyroblasts are elongate and overgrow sillimanite. Biotite occurs

178 scattered in the matrix, or clustered at garnet rims. Sillimanite in the matrix, is scarce, and

179 occurs in seams mantled by plagioclase. Quartz largely occurs as variably recrystallised

180 and resorbed ribbons.

\section{Samples from the GAG}

183 Two of the three samples selected from the GAG (HJ-58c and HJ-57-C2) belong

184 to the sillimanite-rich group, but sillimanite is restricted to a single garnet inclusion in 10-

185 AI-76. Sample HJ-58c consists of a quartzofeldspathic matrix with plagioclase-rich

186 layers, disseminated garnet, biotite and sillimanite, and a few garnet porphyroblasts (Fig.

187 2f). Biotite and sillimanite define a foliation. Garnet porphyroblasts contain inclusions of

188 biotite, sillimanite, quartz, and K-feldspar, and are locally replaced by biotite

189 ( \pm symplectitic with quartz), sillimanite \pm plagioclase.

190 Sample 10-AI-76 is characterized by a K-feldspar-rich matrix with an aluminous

191 nodule, scattered garnet of varied sizes, and interstitial biotite (Fig. 2g). The aluminous

192 nodule consists of spinel, corundum, and sillimanite enclosed in garnet partly overgrown

193 by biotite (Fig. 3g) and mantled by plagioclase. Sample HJ-57-C2 is fine-grained, 
194 homogeneous and rich in quartz and sillimanite (Fig. 2h). It also contains cordierite,

195 which is variably altered to pinite and occurs as wisps in the matrix, as well as associated 196 with garnet (Fig. 3h)

197

198 Interpretation of the microstructures

199 The dominant mineral assemblage and the textures observed in the rocks of the 200 three locations are consistent with the biotite dehydration reaction: biotite + sillimanite +

201 quartz \pm plagioclase $\rightarrow$ melt + garnet + K-feldspar. Acicular sillimanite inclusions within 202 elongate garnet, and relict reactants surrounded by former melt films (to be discussed 203 below) are evidence of this reaction in the forward direction. Furthermore, corrosion of 204 garnet by biotite (locally with quartz symplectites) \pm sillimanite \pm plagioclase is 205 indicative of this reaction in reverse.

206 Cordierite is interpreted as retrograde in sample 10-AI-58-3B1 from the PLV-LM 207 because it replaces garnet and locally, sillimanite (Fig. 3d). However, in the quartz-rich, 208 fine-grained samples 10-AI-58-2A from the PLV-LM, and HJ-57-C2 from the GAG, it is 209 not conclusive whether cordierite is part of the peak assemblage or a retrograde phase 210 because they lack reaction microstructures.

211 The aluminous nodule from sample 10-AI-76 of the GAG is interpreted as a relict 212 hydrothermal alteration feature in Hindemith et al. (2017). The local enrichment of 213 alumina resulted in a chemical potential gradient of $\mathrm{Al}$ in the protolith, and was later 214 overprinted by granulite-facies metamorphism. 
216 presence of former melt, including: pools of feldspar with resorbed quartz \pm sillimanite \pm

217 biotite, variably enclosed in garnet porphyroblasts (Figs 3e, f) and inferred to represent

218 pseudomorphs after melt; biotite-quartz symplectites concentrated at garnet rims (Fig.

$2193 \mathrm{~b}$ ); and straight edges of garnet against former melt inclusions (Figs. 3e; Vernon and

220 Collins, 1988; Sawyer, 1999; and Holness et al.,2011). In addition, the interstitial shape

221 of cordierite in 10-AI-58-3B1 (Fig. 2b) suggests that this phase may have grown in sites

222 formerly occupied by melt, and corrosion of garnet in these sites (Fig. 3d) is consistent

223 with melt crystallization in the cordierite stability field. Finally, a boudinaged

224 quartzofeldspathic layer in the same sample, may represent a former melt pathway.

226 Mineral Chemistry

Some mineral composition data were compiled from previous work (GAG:

228 Strowbridge, 2006; LBS: Hindemith et al., 2017; and 216a: Lasalle and Indares, 2014).

229 Samples from the PLV were analysed at Carleton University on a Cameca Camebax

230 MBX electron microprobe in WDS mode with a $20 \mathrm{kV}$ accelerating potential, a 20nA

231 beam current, and beam size of 5 microns for all minerals except feldspars for which a 10

232 micron beam was used. Additional data from the GAG were acquired at Memorial

233 University of Newfoundland on a JEOL JXA-8230 electron microprobe in WDS mode,

234 using a $15 \mathrm{kV}$ accelerating potential, a $20 \mathrm{nA}$ beam current and a 3 micron beam. The

235 chemical composition ranges of garnet, biotite and feldspars are listed in Tables 2 to 4

236 and key parameters (averages per sample) are graphically presented in Fig. 4. 
238 Garnet

239 In most cases, garnet is almandine-rich, with moderate pyrope, and minor (less 240 than 5\% each) grossular and spessartine contents (Table 2). The composition ranges of 241 garnet from the 3 locations overlap (Figs. 4a, b) and garnets from the PLV-ML have the 242 highest $\mathrm{x}(\mathrm{Fe})$ ratios $(0.64-0.76$ vs $0.53-0.76$ in the and GAG). One exception is garnet in $243 \mathrm{HJ}-57-\mathrm{C} 2(\mathrm{GAG})$ where spessartine reaches $26-34 \%$ of garnet, and $\mathrm{x}(\mathrm{Fe})$ is as low as $2440.30-0.37$. Garnet porphyroblasts in all locations show a $1-7 \%$ increase in almandine and 245 equivalent decrease in pyrope at the rims, whereas small grains are homogeneous.

247 Biotite and Cordierite

248 Biotite is characterized by $\mathrm{x}(\mathrm{Fe})$ in the range of $0.30-0.46$ in the PLV-LM and 249 LBS, and 0.32-0.50 in the GAG, with values as low as 0.06-0.20 in sample HJ-57-C2 250 (Table 3 and Fig. 4c). Ti and $\mathrm{Al}^{\mathrm{VI}}$ contents in biotite cover wide ranges. In individual 251 samples, biotite in contact with garnet has slightly lower $\mathrm{x}(\mathrm{Fe})$ than in the matrix.

252 Cordierite is present in two samples from the PLV-LM, and one from the GAG. It is Mg253 rich, with an $\mathrm{x}(\mathrm{Fe})$ of $0.22-0.26$ in the PLV-LM and 0.05 in the GAG.

Feldspars

The anorthite contents of plagioclase are in the range of 8-30\% (Table 4).

257 Plagioclase from the LBS is the most sodic and that from the PLV-LM is the most calcic

258 (Fig. 4d). Plagioclase grains are generally homogeneous, but there are some exceptions: 
259 in samples from the LBS, and in the sample with aluminous nodules of the GAC (Figs.

$2602 \mathrm{~d}, \mathrm{e}, \mathrm{g})$ plagioclase becomes increasingly An-rich with proximity to garnet (e.g. 8-20\%

261 in the matrix versus 17-20\% near garnet in 331-E2-11; see also Hindemith et al., 2017);

262 and in sample 10-AI-20A from the PLV-LM, plagioclase cores are enriched in Ca

263 relative to the rims. K-feldspar has $\mathrm{Or}_{76-92}$.

265 Interpretation of mineral chemistry

266 The variation in mineral chemistry between samples may reflect differences in the

267 bulk compositions and/or differences in the metamorphic evolution of the three sampled

268 localities. In contrast, variations within individual samples reflect incomplete re-

269 equilibration during cooling from the metamorphic peak.

270 The generally uniform composition of garnet cores is consistent with

271 homogenisation at high metamorphic $T$. The slight increase in $\mathrm{x}(\mathrm{Fe})$ at the rim of garnet

272 porphyroblasts suggests partial resetting during cooling since higher $\mathrm{x}(\mathrm{Fe})$ indicates

273 lower $T$ (Spear, 1991). In combination with the slightly higher spessartine contents at the

274 rim, this zoning is indicative of a retrograde net transfer reaction (Spear, 1991). This is

275 consistent with textural evidence of biotite + sillimanite \pm plagioclase growth at the

276 expense of garnet rims, inferred to have occurred during melt crystallization. In addition,

277 the observation that biotite has the lowest $\mathrm{x}(\mathrm{Fe})$ where it is adjacent to garnet suggests

278 that there was also retrograde Fe-Mg exchange between these two phases (Spear, 1991).

279 Within this framework, the composition of the garnet cores is inferred to represent the

280 highest metamorphic $T$. However, it is possible that at early stages of cooling the 
281 composition of the entire garnet was reset, this being most likely for small garnets that do 282 not show retrograde zoning (Spear, 1991). Therefore, metamorphic conditions predicted 283 by using garnet cores should be considered as 'minimum' peak conditions. Concerning 284 biotite, because a large part of it may have been produced during melt crystallisation, and 285 because its composition resets more easily during cooling (Spear 1991), its composition 286 is not appropriate for the determination of the thermal peak.

288 Phase equilibria modeling

The $P-T$ pseudosections in this study were calculated with THERMOCALC 3.33

290 (Powell and Holland, 1988) using the bulk composition of each sample in the $\mathrm{Na}_{2} \mathrm{O}-$

$\mathrm{CaO}-\mathrm{K}_{2} \mathrm{O}-\mathrm{FeO}-\mathrm{MgO}-\mathrm{Al}_{2} \mathrm{O}_{3}-\mathrm{SiO}_{2}-\mathrm{H}_{2} \mathrm{O}-\mathrm{TiO}_{2}-\mathrm{O}$ (NCKFMASHTO) system. Mn was

292 not considered in this system because of the low contents in the bulk composition and

293 this omission should not affect the results and interpretation significantly, except for HJ-

294 57-C2, which was not used for $P-T$ determinations.

\section{Bulk Compositions}

297

The bulk compositions of the samples were calculated as molar \% of oxides by

298 combining modal proportions and the average chemical composition for each mineral

299 (average of rim and core chemical analysis of many grains in all textural settings),

300 determined with the SEM-MLA and the EMP, respectively. This was the method of

301 choice because: (a) it gives bulk compositions representative of the investigated thin 302 sections; and (b) it allows the calculation of a bulk $\mathrm{H}_{2} \mathrm{O}$ on the basis of the major hydrous 
303 minerals, which is important for the location of the solidus in the pseudosections. It also

304 allows one to exclude secondary minerals and alterations, sulfides, and minor phases such

305 as apatite, monazite and zircon which cannot be accounted for in the NCKFMASHTO

306 system. The bulk $\mathrm{H}_{2} \mathrm{O}$ was calculated as the sum of the $\mathrm{H}_{2} \mathrm{O}$ in biotite and cordierite

307 using the methods outlined in White et al. (2007) and Harley et al. (2002), respectively.

308 The bulk compositions are listed in Table 5, and are plotted on an AFM diagram

309 (Fig. 5). Most have $\mathrm{x}(\mathrm{Fe})$ between 0.50 and 0.63 with the exception of HJ-57-C2.

310 Samples from the PLV-LM have higher alumina index than those from the LBS $(\sim 0.32-$

$3110.50 \mathrm{vs} \sim 0.15-22$ ), whereas the alumina index in those from the GAG has a wide range of

312 values. Samples with an alumina index of $>0.25$ and $<0.25$ correspond to the sillimanite-

313 rich and sillimanite-poor groups, respectively. One sillimanite-rich sample, HJ-57-C2,

314 has an anomalous bulk composition that plots far from the main clusters, with much

315 higher alumina index, and $\mathrm{x}(\mathrm{Mg})$, consistent with advanced argillic alteration.

\section{$P-T$ pseudosections}

318 The calculations used the internally consistent dataset tcds55 (Powell and

319 Holland, 1988), created November 22, 2003, and the phases liquid - quartz - garnet - K-

320 feldpsar - plagioclase - sillimanite - biotite - cordierite - muscovite - rutile - ilmenite -

321 orthopyroxene were considered in the calculations. The following a-x models were used:

322 garnet (White et al., 2007), biotite (White et al., 2007), cordierite (Holland and Powell,

323 1998), muscovite (Coggon and Holland, 2002), plagioclase and K-feldspar (Holland and

324 Powell, 2003), orthopyroxene (White et al., 2002), ilmenite (White et al., 2000) and melt 
325 (White et al., 2007). The NCKFMASHTO system also takes into account $\mathrm{Fe}^{3+}$, which is

326 calculated based on an input value of $\mathrm{O}$ (oxygen) in the bulk composition. For

327 consistency, a low value of oxygen equal to 0.05 was used, which is supported by the

328 scarcity of ilmenite, lack of magnetite and negligible proportion of andradite in garnet.

329 The pseudosections were calculated in the $P-T$ range of 3-14 kbar and 700-1000

$330{ }^{\circ} \mathrm{C}$. The full topologies and mineral proportion isopleths (isomodes) for two

331 pseudosections from each area are shown in Fig. 6, $P-T$ paths and mineral composition

332 isopleths are shown in Fig. 7 within a reduced range of 5-13 kbar and $800-950{ }^{\circ} \mathrm{C}$, as

333 well as melt reintegrated diagrams in Fig. 8. Finally, two additional samples were

334 modeled in Fig. 9 to explore the stability of cordierite in these rocks.

336 General Topologies

337 Within the sillimanite stability field, all topologies of the $P-T$ pseudosections are 338 muscovite-free and can be divided into two main parts: (1) a mid- $P$ area between the 339 cordierite-in boundary and the sillimanite-kyanite transition line, and (2) a low- $P$ area, 340 with cordierite-bearing topologies. Cordierite becomes stable at P conditions below $\sim 5$ to 3418 kbar.

342 Mid- $P$ topologies of the sillimanite-rich samples (Figs. 6a, b, e) are characterized 343 by a sub-vertical solidus within the $T$ range of $810-840{ }^{\circ} \mathrm{C}$, and a sub-vertical biotite-out 344 line at higher $T$. Biotite is completely consumed at $\mathrm{T}<900{ }^{\circ} \mathrm{C}$ in all but in the $P-T$ 345 pseudosection of 10-AI-58-3B1 (Fig. 6b), which is quartz poor (see Table 1). In this case 346 quartz is eliminated first, and biotite is stable up to $1050{ }^{\circ} \mathrm{C}$ (outside of the range of the 
347 diagram). Mid- $P$ topologies of the sillimanite-poor samples show a sub-vertical solidus at $348 \quad 820-870{ }^{\circ} \mathrm{C}$, but up- $T$ orthopyroxene becomes stable before the elimination of biotite 349 (Figs. 6c, d, f), where both biotite and orthopyroxene boundaries have moderate positive $350 \mathrm{~d} P / \mathrm{d} T$ gradients. In these pseudosections, the biotite-out boundary occurs at higher $T$ than 351 in the sillimanite-rich samples (compare Figs 2c, d, f, with Figs 2a, e), and sillimanite is 352 either stable at near solidus conditions (Figs. 5c, d) or is not stable at all in the mid- $P$ 353 topologies (Fig. 5f). The later is the case of samples with sillimanite restricted to garnet 354 inclusions. In addition, some mid- $P$ topologies show a plagioclase-out boundary up- $T$ at 355 near solidus conditions (10-AI-58-3B1 in Fig. 6b which has only retrograde plagioclase), 356 or at higher $T$. Mid- $P$ topologies are generally extended into the kyanite stability field, 357 where muscovite becomes stable on the high- $P /$ low- $T$ side of some pseudosections, but is 358 out of range for others.

359 Low- $P$ topologies are controlled by shallow $\mathrm{d} P / \mathrm{d} T$ gradient field boundaries 360 involving cordierite, garnet and orthopyroxene in the case of the sillimanite-rich samples. 361 Minor phases include one or more of rutile, ilmenite and magnetite, where rutile is stable 362 throughout or on the high- $P$ side when paired with ilmenite.

363 For the samples investigated, the $P-T$ stability field of the inferred peak mineral 364 assemblage (Field I) falls within the mid- $P$ part of the pseudosections. For the sillimanite365 rich samples, the peak assemblage liquid + biotite + garnet + quartz + sillimanite $+\mathrm{K}-$

366 feldspar \pm plagioclase is stable between the solidus and the biotite-out boundary, or 367 between the plagioclase-out and quartz-out boundaries (sample 10-AI-58-3B1; Fig. 6b). 368 For the sillimanite-poor samples, the peak assemblage liquid + biotite + garnet + quartz + 
369 K-feldspar + plagioclase is stable between the solidus and the orthopyroxene-in

370 boundary, in the case where sillimanite is restricted to garnet inclusions (Fig. 6f); or the

371 sillimanite-out and orthopyroxene-in boundaries (Figs. 6c, d). In terms of $T$ and $P$

372 conditions, Field I falls within the range of $820-900^{\circ} \mathrm{C}$ in the PLV-LM and LBS, and

$373 \quad 830-920^{\circ} \mathrm{C}$ in the GAG, at the $P$ interval between $\sim 6-7$ (defined by the cordierite-out

374 boundary) to $10-12 \mathrm{kbar}$ (defined by the sill-ky transition).

375

376

\section{Isomodes and isopleths}

377 The isomodes for plagioclase, sillimanite, biotite, garnet and liquid were

378 calculated in Field I for each sample and are shown in Fig. 6. In this field, the proportions

379 of plagioclase, biotite (and sillimanite in the sillimanite-rich samples) decrease, while

380 liquid and garnet increase with increasing $T$. These trends are consistent with biotite

381 dehydration melting according to a generalized reaction: biotite + quartz \pm sillimanite \pm

382 plagioclase $\rightarrow$ garnet + K-feldspar + melt. The maximum melt fraction within Field I

383 varies between 3 and 10 modal \% at the biotite-out boundary of Field I, and reaches $15 \%$

384 at the quartz-out boundary in the case of 10-AI-58-3B1 (Fig. 6b). These values seem to

385 be correlated with the proportion of biotite in the solidus (and the $T$ interval between the

386 solidus and the biotite-out boundary) in accordance to the above mentioned reaction.

387 The isopleths $\mathrm{x}(\mathrm{g}), \mathrm{z}(\mathrm{g}), \mathrm{ca}(\mathrm{pl})$ and $\mathrm{x}(\mathrm{bi})$ in Field I for each sample are shown in

388 Fig. 7. These are defined in THERMOCALC as $x(g)=\mathrm{Fe} /(\mathrm{Fe}+\mathrm{Mg})$ and $\mathrm{z}(\mathrm{g})=$

$389 \mathrm{Ca} /(\mathrm{Fe}+\mathrm{Mg}+\mathrm{Ca})$ of garnet, $\mathrm{ca}(\mathrm{pl})$ is the anorthitic content in plagioclase, and $\mathrm{x}(\mathrm{bi})$ is

$390 \mathrm{Fe} /(\mathrm{Fe}+\mathrm{Mg})$ of biotite. Within the fields of interest, the $\mathrm{x}(\mathrm{g})$ and $\mathrm{x}(\mathrm{bi})$ isopleths have a 
391 steep, positive $\mathrm{d} P / \mathrm{d} T$ gradient and their values decrease with increasing $T$ except where

392 the peak mineral assemblage is sillimanite-free, in which case they have a steep negative

$393 \mathrm{~d} P / \mathrm{d} T$ gradient (Figs $7 \mathrm{c}, \mathrm{d}, \mathrm{f})$. The $\mathrm{z}(\mathrm{g})$ isopleths generally have a shallow positive $\mathrm{d} P / \mathrm{d} T$

394 gradient and values that increase with $P$, however, in fields that lack plagioclase, $\mathrm{z}(\mathrm{g})$

395 becomes sub-vertical, and in sillimanite-absent fields, these have a moderate negative

396 slope. Isopleths of ca(pl) typically have moderate positive $\mathrm{d} P / \mathrm{d} T$ gradients.

397

398

\section{$P-T$ paths}

399 The $P-T$ pseudosections discussed above can potentially constrain the $P-T$ evolution of 400 the investigated rocks within the $P-T$ field(s) of the observed mineral assemblages. For

401 instance, (a) the intersection of relevant garnet composition isopleths corresponding to

402 measured garnet compositions, can be used to narrow down the peak $P-T$ conditions; and

403 (b) because the retrograde phases produced depend on the angle at which the $P-T$ path 404 cuts their isomodes, the distribution of these isomodes can be used to predict the shape of 405 the $P-T$ paths during melt crystallization. In addition, the actual mineral proportions in 406 the rock compared with those along the solidus should match at the $P-T$ conditions of 407 melt crystallization.

408 Table 6 shows the $\mathrm{x}(\mathrm{g}), \mathrm{x}(\mathrm{bi})$ and $\mathrm{z}(\mathrm{g})$ isopleths for each sample, and the 409 predicted $P-T$ coordinates of the peak and of melt crystallization. Isopleths $\mathrm{z}(\mathrm{g})$ and $\mathrm{x}(\mathrm{g})$

410 from the cores of large garnet were used to constrain the peak $P-T$ and isopleths $\mathrm{x}(\mathrm{bi})$ are

411 shown for comparison. However, in several cases, the $\mathrm{x}(\mathrm{g})$ isopleths, which are $T$ -

412 dependent, are close to the solidus, suggesting potential reequilibration of garnet cores 
413 during cooling. Additionally, isopleths of $z(g)$ are widely spaced in the fields of interest 414 and provide little constrain on the $P$ of the peak and of melt crystallization. Finally, the

415 mineral modes do not change significantly along the solidus between the cordierite

416 boundary and the sillimanite-kyanite transition line, so the $P$ of melt crystallization

417 cannot be well constrained unless the sample has retrograde cordierite (see Table 7 for

418 comparison of mineral modes at the solidus with the modes of the thin section). For these

419 reasons, a range of possible $P-T$ paths are shown in grey (Fig. 7).

420 The $P-T$ paths for the samples from the PLV-LM are shown in Figs. $7 \mathrm{a}$ and $\mathrm{b}$.

421 The minimum peak $T$ and $P$ predicted by the intersection of $\mathrm{z}(\mathrm{g})$ and $\mathrm{x}(\mathrm{g})$ isopleths is

$422840-865^{\circ} \mathrm{C}$ and $9-11 \mathrm{kbar}$. The moderate replacement of porphyroblastic garnet by

423 biotite + sillimanite \pm plagioclase \pm quartz in these rocks is consistent with the retrograde

424 portion of the $P-T$ path cutting the isomodes for these phases at a high angle, therefore

425 following a moderate $\mathrm{d} P / \mathrm{d} T$ gradient. In addition, the presence of retrograde cordierite in

426 10-AI-58-3B1, constrains the $P-T$ path in Fig. $7 \mathrm{~b}$ to cross the solidus in the cordierite

427 stability field (at $\sim 820-840^{\circ} \mathrm{C}$ and $6-7 \mathrm{kbar}$ ).

428 For the two samples from the LBS, the $\mathrm{x}(\mathrm{g})$ isopleths coincide with the solidus so 429 the peak $T$ is only constrained by the entire $T$ range of Field $\mathrm{I}$, at $830-875^{\circ} \mathrm{C}$ with a $P$ of $430 \quad 8-11 \mathrm{kbar}$ (Figs. 7c, d). The replacement of garnet rims by biotite in these samples is 431 consistent with a $P-T$ path at an angle to the biotite isomodes and a peak $T$ that is higher 432 than the $T$ of the solidus. The conditions of melt solidification were constrained to $825-$ $433875^{\circ} \mathrm{C}$ and $6.5-8 \mathrm{kbar}$ based on the lack of orthopyroxene and cordierite. The lack of 
434 retrograde sillimanite in these samples is consistent with sillimanite becoming stable in 435 the pseudosections at near solidus conditions.

436 In the pseudosections of the two samples from the $\mathrm{GAG}$, the $\mathrm{x}(\mathrm{g})$ isopleths

437 coincide with the solidus, however, based on the $T$ range of Field I in each sample and 438 the $\mathrm{z}(\mathrm{g})$ isopleth of the garnet core, the peak $T$ is constrained to $840-845^{\circ} \mathrm{C}$ at $P$ of $8-11$

439 kbar (Figs. 7e, f). Partial replacement of garnet rims by sillimanite and biotite is

440 consistent with a shallow to moderate $\mathrm{d} P / \mathrm{d} T$ gradient. Because of the lack of cordierite in

441 these samples, the $P-T$ path may cross the solidus anywhere above the cordierite or

442 orthopyroxene boundaries, at $835-840{ }^{\circ} \mathrm{C}$ and $6-8 \mathrm{kbar}$.

443

444 Melt reintegration

445 All the $P-T$ pseudosections discussed earlier are characterized by a steep solidus 446 and the lack of muscovite from the mid- $P$ topologies. These features, together with the 447 good preservation of the peak mineral assemblages, are consistent with some melt loss 448 (White and Powell, 2002). This is common for anatectic rocks in orogenic environments 449 because the melt is squeezed out under deviatoric stress (Brown, 2007). The current bulk 450 compositions therefore represent those attained after the loss of melt. Considering this, 451 topologies calculated at $T$ below the solidus (liq $=0$ line) in these diagrams are not valid, 452 and this hampers the prediction of prograde $P-T$ paths. For this reason, additional 453 pseudosections were calculated using melt-reintegrated compositions for selected 454 samples to outline the topologies relevant to the prograde $P-T$ paths. 
To construct these diagrams, the composition of the first infinitesimal amount of

456 melt was calculated where the prograde portion of the path was projected to have crossed

457 the solidus. Although this $P$ is not well constrained, it has been shown that the

458 suprasolidus topologies of the melt-reintegrated pseudosections are not significantly

459 affected by $P$ (Indares et al., 2008; Groppo et al., 2012). Proportions of melt with this

460 composition were then added to the original bulk composition until an amount sufficient

461 to make the water saturated solidus stable was achieved. Therefore, in using this method,

462 we assume that the rock was water saturated and that the melt loss occurred in one step.

463 It is not possible to calculate the exact amount of lost melt, and in the case of

464 rocks with complex earlier histories, as the ones investigated here, the assumption of

465 water saturated solidus is questionable. However, it has been determined that the

466 suprasolidus topologies of the melt-reintegrated pseudosections do not change

467 significantly with varying quantities of added melt because they are largely controlled by

468 the solid phases (White and Powell, 2002). Therefore, these melt-reintegrated phase

469 equilibria diagrams can provide some insight on the prograde portion of the paths, and, in

470 addition, allow one to assess the potential melt productivity of the examined rock types.

471 Fig. 8 displays melt-reintegrated $P-T$ pseudosections for 5 samples, a diagram for

472 sample 216a is not included because of difficulties in calculating it. In each diagram, the

473 thick dashed white line represents the "dry" solidus calculated with the actual bulk

474 compositions of the rock (before melt reintegration; see Fig. 6). The "wet" solidus in the

475 melt-reintegrated diagrams occurs at much lower $T$, outside of the range of the

476 pseudosection. The portion of the pseudosection at $T$ above the "dry" solidus is quite 
477 similar in the both the original and melt-reintegrated pseudosections, and therefore will 478 not be discussed again here.

479 The amount of melt added in order to produce a water-saturated solidus was 480 higher (20-25 modal \%) in the sillimanite-rich samples HJ-58c and 10-AI-20-A, and 481 much lower (8-12 modal \%) in the sillimanite poor samples (331-e2-11 and 10-AI-76)

482 and in the sillimanite-rich but quartz-poor 10-AI-58-3B1. The higher range compares 483 well with that calculated by Lasalle and Indares (2014) for sillimanite-rich rocks from the 484 LBS and a metapelite from the PLV.

485 In the melt-reintegrated diagrams, melt isomodes increase with $T$ between the wet 486 solidus and biotite-out boundary (the dehydration melting region), and have moderate $487 \mathrm{~d} P / \mathrm{d} T$ slopes (compared with steep $\mathrm{d} P / \mathrm{d} T$ slopes in the original bulk pseudosections). For 488 the sillimanite-rich samples, the predicted amount of melt reaches $\sim 36-40 \%$ at the 489 biotite-out boundary, and 30\% at the quartz-out boundary in 10-AI-58-3B1 (Figs. 8a, b, $490 \mathrm{~d})$. In contrast, the predicted melt production for the sillimanite-poor samples at the same 491 boundary reaches only $\sim 20-30 \%$ (Fig. 8c, e). Melt production in the melt reintegrated 492 pseudosections is much greater between the conditions of the dry solidus and the biotite493 out boundary than in pseudosections calculated using the original bulk compositions.

\section{General topologies in melt reintegrated pseudosections and $P-T$ paths}

For all samples, the stability field of muscovite has been shifted to lower $P$ in the

497 melt-reintegrated diagrams. The appearance of sillimanite or K-feldspar coincides 498 approximately with the disappearance of muscovite for at least a portion of the muscovite 
499 boundary. A sub-vertical garnet-in boundary occurs at the $T$ range of $700-800{ }^{\circ} \mathrm{C}$.

500 Because Mn, which expands the stability of garnet to lower $T$ (White et al., 2014), was

501 not considered in the bulk composition, yet a small percentage of garnet is spessartine,

502 the $T$ of the garnet-in boundary in the pseudosections is likely overestimated.

503 The prograde portions of the $P-T$ paths were constrained by the sillimanite-

504 kyanite transition line since garnet overgrows sillimanite to a large extent. This is

505 consistent with a moderate $\mathrm{d} P / \mathrm{d} T$ prograde $P-T$ path. For sample $10-\mathrm{AI}-76$, there is field

506 where sillimanite becomes stable below the "dry" solidus within the $T$ range of 700-800

$507{ }^{\circ} \mathrm{C}$. This explains the presence of sillimanite in this sample only as inclusions in garnet.

508

509 The effect of bulk composition on cordierite stability

510 Unlike sample 10-AI-58-3B1, where cordierite clearly replaces garnet, samples

511 10-AI-58-2a and HJ-57-C2 have significant cordierite distributed throughout the matrix

512 as wispy aggregates (Figs. 2c, 3c). These samples are fine-grained therefore prone to

513 extensive retrograde re-equilibration. Because of this, it is inconclusive as to whether or

514 not cordierite is part of the peak assemblage. Although these samples were not used to

515 infer $P-T$ conditions and paths, their pseudosections are included in Fig. 9 to investigate

516 the role of bulk composition on the stability of cordierite. Both samples are part of the

517 sillimanite-rich group.

518 It is known that increasing $\mathrm{x}(\mathrm{Mg})=\mathrm{Mg} /(\mathrm{Fe}+\mathrm{Mg})$ expands the cordierite stability

519 field to higher $P$ (Spear et al. 1999; Groppo et al., 2013) and this correlation can be seen

520 to some extent by comparing the $\mathrm{x}(\mathrm{Mg})$ of the bulk compositions (Table 5) with the 
521 locations of the cordierite-in boundary in the calculated pseudosections. In particular by

522 comparing the $P$ of the intersection between the solidus and the cordierite-in boundary

523 with the bulk $\mathrm{x}(\mathrm{Mg})$, samples can be divided into three groups. (1) Sample 10-AI-76 has

524 the lowest $\mathrm{x}(\mathrm{Mg})$ at $<0.40$, and correspondingly, the lowest $P$ at which cordierite

525 becomes stable, $\sim 5 \mathrm{kbar}$ (Fig. 6f). (2) The majority of the samples have an intermediate

$526 \mathrm{x}(\mathrm{Mg})$ in the range of $0.40-0.50$, and for these cordierite becomes stable between 6.01

527 and 7.11 kbar. (3) Finally, in HJ-57-C2, which has the highest $\mathrm{x}(\mathrm{Mg})$ of 0.74 , cordierite is

528 stable up to $\sim 8 \mathrm{kbar}$ (Fig.9b). The high spessartine contents of garnet in this sample yet

529 lack of Mn used in the model may have affected the locations of boundaries in the phase

530 equilibrium diagram, and may explain the difficulty in calculating lower- $P$ boundaries. In

531 samples with the lowest $\mathrm{x}(\mathrm{Mg})$ and $P$ of the cordierite-in boundary, orthopyroxene

532 becomes stable before cordierite. Additionally, in fields that are sillimanite-absent,

533 cordierite first becomes stable at lower $P$ compared with samples with similar $\mathrm{x}(\mathrm{Mg})$ in

534 sillimanite-present fields.

535 Based on the $P$ of the cordierite-in boundary compared with the $P-T$ paths from

536 each area, it is likely that cordierite was not part of the peak assemblage of 10-AI-58-2a

537 (Fig. 9a) since the peak- $P$ is much higher than that at which cordierite first becomes

538 stable ( $\sim 6.5-7.5 \mathrm{kbar}$ for the cordierite boundary compared with $8-11 \mathrm{kbar}$ for the peak- $P$

539 of other samples in the area). However, because the cordierite-in boundary occurs at $\sim 8-9$

540 kbar between the solidus and biotite boundaries in $\mathrm{HJ}-57-\mathrm{C} 2$, it is possible that cordierite

541 was a peak phase in this sample.

542 


\section{Summary and conclusions}

544 Aluminous gneisses derived from hydrothermally altered protoliths have been

545 recognized in three distinct lithologic units and locations in the Manicouagan and Lac du

546 Milieu areas, in the hinterland of the Central Grenville Province. These rocks were

547 metamorphosed under mid- $P$ granulite facies-conditions during the Grenvillian orogeny,

548 and contain the mineral assemblage garnet + biotite + quartz + K-feldspar \pm plagioclase \pm

549 sillimanite \pm cordierite with a wide range of mineral proportions and microstructures, as

550 well as evidence for anatexis.

551 In terms of the mode of occurrence (\& proportion) of sillimanite, the rocks can be

552 classified into: (a) sillimanite-rich samples, which have sillimanite present in the peak

553 metamorphic assemblage and show a high Alumina index on AFM space; and (b)

554 sillimanite-poor samples, with sillimanite only as inclusions in garnet and with a low

555 Alumina index. In addition, some samples are quartz-rich and fine grained.

556 Microstructural evidence of former melt is preserved in all rocks except the

557 quartz-rich varieties, as former melt inclusions in garnet pseudomorphed by feldspars,

558 relict quartz grains surrounded by thin feldspar rims, inter-granular films in the matrix

559 and biotite-quartz symplectites. In addition, the interstitial form of cordierite in the matrix

560 of some samples suggest that this phase may have pseudomorphed former melt pockets.

$561 P-T$ pseudosections (in the NCKFMASHTO system) calculated with the

562 measured bulk compositions show different topologies for the sillimanite-rich and poor

563 samples, and the predicted phase relations support microstructural evidence that in the

564 later samples, sillimanite is an earlier prograde phase, not stable at the thermal peak. In 
565 addition, they provide the framework to assess the effect of the bulk $\mathrm{x}(\mathrm{Mg})$ on the

566 stability of cordierite, and support microstructural evidence that cordierite is of retrograde

567 origin. The $P-T$ pseudosections are generally consistent with observed mineral

568 assemblages and compositions, with the exception of 10-AI-76. This sample has an

569 aluminous nodule containing spinel and sillimanite that was not predicted by the

570 pseudosection. This is because of the locally enriched Al bulk composition as a result of

571 relict hydrothermal alteration texture.

572 In all these $P-T$ pseudosections, a lower- $T$ limit for the conditions of the thermal

573 peak is constrained by the solidus whereas the upper- $T$ limit is placed by: orthopyroxene-

574 out boundary in some sillimanite-poor rocks in which orthopyroxene appears before the

575 elimination of biotite, and the biotite-out boundary in all other rocks (except for a quartz-

576 poor variety). However, use of this limit implies that biotite was stable at the thermal

577 peak, which is not obvious based on the observed microstructures. In addition, the use of

578 mineral composition isopleths to constrain peak $P-T$ conditions in these mid- $P$ granulite

579 facies rocks was limited because of potential partial resetting of $\mathrm{x}(\mathrm{Mg})$ isopleths of

580 garnet, which is $T$ dependent, during cooling, and the wide spacing of $\mathrm{z}(\mathrm{g})$ isopleths of

581 garnet in the mid- $P$ range.

582 The $P-T$ conditions of the metamorphic peak predicted by the $P-T$

583 pseudosections fall in the range $830-875^{\circ} \mathrm{C}$ at $8-10 \mathrm{kbar}$, the lower $T$ part of which is

584 probably underestimated owing to the limitations discussed above. In addition, the melt is

585 predicted to have solidified upon cooling down to at a $T$ of $800-865^{\circ} \mathrm{C}$ at $6-9 \mathrm{kbar}$

586 (Table 2.6). In this case, the $T$-range corresponds to the different locations of the dry 
587 solidus in the different samples. The $P$ of melt solidification is better constrained in 588 samples that contain retrograde cordierite, because in this case it corresponds to the 589 intersection between the solidus and the cordierite boundary. In addition, local retrograde 590 replacement of garnet by biotite \pm sillimanite in most samples require retrograde $P-T$ 591 paths with moderate $\mathrm{d} P / \mathrm{d} T$ gradients. The prograde portion of the $P-T$ paths was 592 investigated by means of melt-reintegrated $P-T$ pseudosections, and based on 593 microstructural grounds they were constrained to fall below the sillimanite/kyanite 594 transition.

595 The two sets of $P-T$ pseudosections (calculated with the measured $v s$ melt 596 reintegrated bulk compositions) provide also some insight on the melt productivity of the 597 modeled bulk compositions. The melt proportions predicted at the biotite-out boundary in 598 the $P-T$ pseudosections calculated with the measured bulk compositions are mainly 599 correlated with the proportion of biotite in the solidus. In contrast, the melt proportions 600 calculated at the same boundary, in the melt reintegrated $P-T$ pseudosections are 601 correlated with the rock type, and are highest for the sillimanite-bearing samples. 602 Metamorphic $P-T$ paths predicted by the $P-T$ pseudosections, by comparing 603 textural and mineral composition data of the rocks with the calculated topologies, are 604 broadly similar in all locations and rock types. The generalized $P-T$ path has an overall 605 "tilted hair pin" shape with a moderate $\mathrm{d} P / \mathrm{d} T$ gradient. The data suggest that this part of 606 the mid- $P$ hinterland in the central Grenville experienced a uniform metamorphic 607 evolution, with large $T$ variations relative to $P$, consistent with the thermal evolution of 608 middle crust beneath an orogenic plateau. 


\section{Acknowledgements}

611 This contribution is derived from the MSc Thesis of MP that was funded by the NSERC

612 Discovery Grant of AI. We would like to thank M. Shaffer and D. Grant (CREAIT,

613 MUN) for their assistance with SEM-MLA mapping, Peter Jones for microprobe analysis

614 at Carleton University, and Wanda Aylward (CREAIT, MUN) for assistance with the

615 microprobe at MUN. We also thank Dr. Chiara Groppo for her insightful review and Dr.

616 Ali Polat for handling the manuscript.

617

\section{References}

620 Beaumont, C., Nguyen, M.H., Jamieson, R.A., and Lee, B. 2006. Crustal flow modes in

621 large hot orogens. Geological Society of London Special Publication, 268: 91-145.

622 Bonnet, A. L., and Corriveau, L. 2007. Alteration vectors to metamorphic hydrothermal

623 systems in gneissic terranes. In Mineral Deposits of Canada: A Synthesis of Major

624 Deposit-Types, District Metallogeny, the Evolution of Geological Provinces, and

625 Exploration Methods. W.D. Goodfellow (eds.). Geological Association of Canada,

626 Mineral Deposits Division, Special Publication 5, pp. 1035-1049.

627 Brown, M. 2007. Crustal melting and melt extraction, ascent and emplacement in

628 orogens: mechanism and consequences. Journal of Geological Society of

629 London, 164: 709-730.

630 Coggon, R. and Holland, T. J. B., 2002. Mixing properties of phengitic micas and revised 631 garnet-phengite thermobarometers. Journal of Metamorphic Geology, 20: 683-696. 
632 Dunning G, and Indares, A., 2010. New insights on the 1.7-1.0 Ga crustal evolution of 633 the central Grenville from the Manicouagan-Baie Comeau transect. Precambrian $634 \quad$ Research, 180: 204-226.

635 Gower, C. F. and Krogh, T. E., 2002. A U-Pb geochronological review of the Proterozoic 636 history of the eastern Grenville Province. Canadian Journal of Earth

$637 \quad$ Sciences, 39: 795-829.

638 Groppo, C., Rolfo, F. and Indares, A., 2012. Partial melting in the Higher Himalayan 639 Crystallines of Eastern Nepal: the effect of decompression and implications for the 640 “channel flow” model. Journal of Petrology, 53: 1057-1088.

641 Groppo, C., Rolfo, F., and Mosca, P. 2013. The cordierite-bearing anatectic rocks of the 642 higher Himalayan crystallines (eastern Nepal): low-pressure anatexis, melt 643 productivity, melt loss and the preservation of cordierite. Journal of Metamorphic 644 Geology, 31: 187-204.

645 Harley, S. L., Thompson, P. P., Hensen, B. J., and Buick, I. S. 2002. Cordierite as a 646 sensor of fluid conditions in high-grade metamorphism and crustal anatexis. Journal of 647 Metamorphic Geology, 20(1): 71-86.

648 Hindemith, M. A., Indares, A., and Piercey, S. 2017. Hydrothermally altered volcanic 649 rocks metamorphosed at granulite-facies conditions: an example from the Grenville 650 Province. Canadian Journal of Earth Sciences, pagination not final.

651 Holland, T. J. B. and Powell, R., 1998. An internally-consistent thermodynamic data set 652 for phases of petrological interest. Journal of Metamorphic Geology, 16: 309-343. 
653 Holland, T. J. B. and Powell, R., 2003. Activity-composition relations for phases in 654 petrological calculations: an asymmetric multicomponent formulation. Contributions 655 to Mineralogy and Petrology, 145: 492-501.

656 Holness, M.B., Cesare, B., and Sawyer E.W. 2011. Melted Rocks under the Microscope: 657 Microstructures and Their Interpretation. Elements, 7: 247-252

658 Indares, A. and Letourneau, M., in press. Pétrologie et géochimie des roches alumineuses 659 du Complexe de la Plus-Value (Grenville central), Côte-Nord. In Moukhsil, A., 660 Solgadi, F., and Clark, T. (eds.). Géologie et ressources minérales de la région du 661 réservoir Daniel-Johnson (Manicouagan), Province de Grenville central, Côte-Nord, 662 Québec: Ministère de l'Énergie et des Ressources naturelles, Québec.

663 Indares, A. and Moukhsil, A., 2013. Geon 12 crustal extension in the central Grenville 664 Province, implications for the orogenic architecture and potential influence on the 665 emplacement of anorthosites. Canadian Journal of Earth Sciences, 50: 955-966. 666 Indares, A., and Dunning, G. 2004. Crustal architecture above the high-pressure belt of 667 the Grenville Province in the Manicouagan area: new structural, petrologic and $\mathrm{U}-\mathrm{Pb}$ 668 age constraints. Precambrian Research, 130: 199-208.

669 Indares, A.D., White, R.W., and Powell, R., 2008. Phase equilibria modelling of kyanite 670 bearing anatectic paragneisses from the central Grenville Province. Journal of 671 Metamorphic Geology, 26: 815-836.

672 Lasalle, S., Dunning,G., and Indares, A., 2014. In situ LA-ICP-MS dating of monazite 673 from aluminous gneisses: insights on the tectono-metamorphic history of a granulite- 
674 facies domain in the central Grenville Province. Canadian Journal of Earth Sciences, $675 \quad 51,558-572$.

676 Lasalle, S., Fisher, C.M., Indares, A., and Dunning, G., 2013. Contrasting types of

677 Grenvillian granulite facies aluminous gneisses: insights on protoliths and 678 metamorphic events from zircon morphologies and ages. Precambrian Research, 228:

$679 \quad 117-130$.

680 Lasalle, S. and Indares, A. (2014) Anatectic record and contrasting $P-T$ paths of 681 aluminous gneisses from the central Grenville Province. Journal of Metamorphic 682 Geology, 32: 627-646.

683 Moukhsil, A., Solgadi, F., Lacoste, P., Gagnon, M., and David, J., 2012. Geologie de la 684 region du lac du Milieu. Ministere des Ressources naturelles et de la Faune, RG 2012$685 \quad 01,1-33$.

686 Powell, R., Holland, T.J.B. 1988 An internally consistent thermodynamic dataset with 687 uncertainties and correlations: 3. Applications to geobarometry, worked examples and 688 a computer program. Journal of Metamorphic Geology, 6: 173-204

689 Rivers, T., 2008 Assembly and preservation of lower, mid and upper orogenic crust in the 690 Grenville Province - Implications for the evolution of large hot long-duration orogens. $691 \quad$ Precambrian Research, 167: 237-259.

692 Rivers, T., 2012. Upper-crustal orogenic lid and mid-crustal core complexes: signature of 693 a collapsed orogenic plateau in the hinterland of the Grenville Province. Canadian $694 \quad$ Journal of Earth Sciences, 49: 1-42. 
695 Rivers T, Culshaw N, Hynes A, Indares A, Jamieson R, and Martignole J. 2012. The

696 Grenville Orogen - A post-LITHOPROBE perspective. Chapter 3 In Tectonic Styles

697 in Canada: The LITHOPROBE Perspective. (eds JA Percival, FA Cook, and RM

698 Clowes) Geological Association of Canada, Special Paper 49: 97-236.

699 Rivers, T. and Corrigan, D. 2000. Convergent margin on southeastern Laurentia during

700 the Mesoproterozoic: tectonic implications. Canadian Journal of Earth Sciences, 37:

$701 \quad 359-383$.

702 Sawyer, E. W., 1999. Criteria for the recognition of partial melting. Physics and

703 Chemistry of the Earth, 24, 269-279.

704 Spear, F., 1991. On the interpretation of peak metamorphic temperatures in light of

705 garnet diffusion during cooling. Journal of Metamorphic Geology, 9: 379-388.

706 Spear, F., Kohn, M.J., Cheney, J.T., 1999. P-T paths from anatectic pelites.

707 Contributions to Mineralogy and Petrology, 134: 17-32.

708 Strowbridge, S., 2006. Metamorphic evolution of anatectic metapelites from the Gabriel

709 high strain zone, Grenville Province. Masters Thesis. Memorial University of

$710 \quad$ Newfoundland.

711 Vernon, R. H. and Collins, W. J., 1988. Igneous microstructures in migmatites. Geology,

$712 \quad 16,1126-1129$.

713 White, R.W. and Powell, R. 2002. Melt loss and the preservation of granulite facies

714 assemblages. Journal of Metamorphic Geology, 20: 621-632.

715 White, R. W., Powell, R., and Clarke, G. L., 2002. The interpretation of reaction textures

716 in Fe-rich metapelitic granulites of the Musgrave Block, central Australia: constraints 
717 from mineral equilibria calculations in the system $\mathrm{K} 2 \mathrm{O}-\mathrm{FeO}-\mathrm{MgO}-\mathrm{A} 12 \mathrm{O} 3-\mathrm{SiO} 2-$

718 H2O-TiO2-Fe2O3. Journal of Metamorphic Geology, 20: 621-632.

719 White, R.W., Powell, R., and Holland, T.J.B., 2007. Progress relating to calculation of

720 partial melting equilibria for metapelites. Journal of Metamorphic Geology, 25: 511-

$721 \quad 527$.

722 White, R. W., Powell, R., Holland, T. J. B., and Worley, B. A., 2000. The effect of TiO2

723 and $\mathrm{Fe} 2 \mathrm{O} 3$ on metapelitic assemblages at greenschist and amphibolite facies

724 conditions: mineral equilibria calculations in the system $\mathrm{K} 2 \mathrm{O}-\mathrm{FeO}-\mathrm{MgO}-\mathrm{A} 12 \mathrm{O} 3-$

725 SiO2-H2O-TiO2-Fe2O3. Journal of Metamorphic Geology, 18: 497-511.

726 White, R. W., Powell, R., and Johnson, T. E., 2014. The effect of Mn on mineral stability

727 in metapelites revisited: new a-x relations for manganese-bearing minerals. Journal of

$728 \quad$ Metamorphic Geology, 32: 809-828. 
Table 1. Mineral modes.

\begin{tabular}{|c|c|c|c|c|c|c|c|c|}
\hline & \multicolumn{3}{|c|}{ PLV } & \multicolumn{2}{|c|}{ LBS } & \multicolumn{3}{|c|}{ GAG } \\
\hline Mineral & $\begin{array}{c}10-\mathrm{AI}- \\
20 \mathrm{~A}\end{array}$ & $\begin{array}{l}10-\mathrm{AI}- \\
58-3 \mathrm{~B} 1 \\
\end{array}$ & $\begin{array}{c}10-\mathrm{AI}-58- \\
2 \mathrm{~A}\end{array}$ & $\begin{array}{c}331-\mathrm{e} 2- \\
11 \\
\end{array}$ & $216 \mathrm{a}$ & $\mathrm{HJ}-58 \mathrm{c}$ & $\begin{array}{l}10- \\
\text { AI- } \\
76\end{array}$ & $\begin{array}{l}\mathrm{HJ}- \\
57 \mathrm{c} 2\end{array}$ \\
\hline Garnet & 7.10 & 9.57 & 4.43 & 3.64 & 12.48 & 13.98 & 4.75 & 0.16 \\
\hline Biotite & 12.20 & 34.84 & 7.47 & 19.01 & 4.09 & 6.75 & 5.20 & 5.38 \\
\hline Sillimanite & 5.31 & 30.92 & 3.55 & 0.59 & 0.50 & 1.99 & 0.02 & 9.41 \\
\hline Cordierite & 0.05 & 2.25 & 2.84 & 0.00 & 0.00 & 0.00 & 0.00 & 0.76 \\
\hline Sum Al & 24.66 & 77.58 & 18.29 & 23.25 & 17.94 & 22.73 & 9.98 & 15.71 \\
\hline Sill/Altot & 21.55 & 39.86 & 19.41 & 2.53 & 2.77 & 8.77 & 0.21 & 59.90 \\
\hline Quartz & 36.57 & 12.53 & 68.86 & 14.88 & 32.12 & 35.08 & 23.26 & 73.65 \\
\hline K-Feldspar & 27.36 & 6.51 & 4.39 & 39.35 & 30.27 & 12.70 & 48.67 & 10.49 \\
\hline Plagioclase & 11.39 & 3.30 & 8.40 & 22.15 & 19.22 & 29.13 & 17.69 & 0.06 \\
\hline Sum $Q F$ & 75.32 & 22.35 & 81.65 & 76.38 & 81.61 & 76.90 & 89.62 & 84.21 \\
\hline Rutile & 0.00 & 0.02 & 0.03 & 0.00 & 0.36 & 0.28 & 0.00 & 0.08 \\
\hline Magnetite & 0.02 & 0.00 & 0.00 & 0.00 & 0.08 & 0.09 & 0.00 & 0.00 \\
\hline Ilmenite & 0.00 & 0.05 & 0.02 & 0.38 & 0.00 & 0.00 & 0.16 & 0.00 \\
\hline Spinel & 0.00 & 0.00 & 0.00 & 0.00 & 0.00 & 0.00 & 0.25 & 0.00 \\
\hline Group & SR & SR & SR & SP & SP & SR & SP & SR \\
\hline
\end{tabular}

Sum Al: Sum of aluminous minerals; Sum QF: Sum of quartzofeldspathic minerals; Sill/Al $1_{\text {tot }}$ : Sillimanite proportion divided by Sum Al; SR: Sillimanite-rich; SP: Sillimanite-poor 
Table 2. Compositional ranges of garnet.

\begin{tabular}{llccccc} 
& \multicolumn{7}{c}{ End Members of Grt (\%) } & x(Fe) \\
Location & Sample & Alm & Prp & Grs(+And*) & Sps & $(\%)$ \\
\hline PLV-LM & 10-AI-58-3B1 & $64.4-71.7$ & $23.8-31.5$ & $2.65-2.94$ & $1.12-1.66$ & $64.4-71.7$ \\
PLV-LM & 10-AI-20A & $65.2-75.7$ & $19.4-29.6$ & $2.25-3.23$ & $1.98-2.67$ & $65.1-75.7$ \\
PLV-LM & 10-AI-58-2A & $67.3-72.2$ & $23.7-28.7$ & $2.94-3.13$ & $0.89-1.05$ & $68.4-72.2$ \\
\hline LBS $^{1}$ & $331-\mathrm{e} 2-11$ & $62.3-68.0$ & $20.5-37.1$ & $7.3-10.2$ & $1.0-3.1$ & $62.7-76.1$ \\
LBS $^{1}$ & 216a & $51-65$ & $30-46$ & $3-4$ & $0-1$ & $53-68$ \\
\hline GAG $^{2}$ & HJ-58C & $61-65$ & $32-36$ & $2-3$ & 1 & $63-67$ \\
GAG $^{1}$ & $10-A I-76$ & $64.3-65.9$ & $22.3-25.2$ & $6.3-6.6$ & $4.5-4.9$ & $72.0-74.5$ \\
GAG & HJ-57-C2 & $21.1-23.2$ & $39.2-48.0$ & $4.0-4.9$ & $26.6-34.4$ & $30.6-36.9$ \\
\hline
\end{tabular}

${ }^{1}$ Hindemith et al. (2017) ${ }^{2}$ Strowbridge (2006) *Andradite is negligible Alm: Almandine; Prp: Pyrope; Grs: Grossular; Sps: Spessartine, And: Andradite $\mathrm{x}(\mathrm{Fe})=\mathrm{Fe} /(\mathrm{Fe}+\mathrm{Ca}+\mathrm{Mg})$

Table 3. Compositional ranges of biotite and cordierite.

\begin{tabular}{llllccc} 
& \multicolumn{9}{c}{ Biotite } & Cordierite \\
\hline Location & Sample & Ti (p.f.u) & $\begin{array}{l}\text { Al(VI) } \\
\text { (p.f.u })\end{array}$ & $\begin{array}{c}\mathrm{x}(\mathrm{Fe}) \\
(\%)\end{array}$ & $\mathrm{F}$ & $\begin{array}{c}\mathrm{x}(\mathrm{Fe}) \\
(\%)\end{array}$ \\
\hline PLV-LM & 10-AI-58-3B1 & $0.27-0.30$ & $0.15-0.17$ & $39-42$ & $0.09-0.11$ & $21.8-25.5$ \\
PLV-LM & 10-AI-20A & $0.06-0.22$ & $0.24-0.36$ & $30-42$ & $0.14-0.23$ & $\mathrm{X}$ \\
PLV-LM & 10-AI-58-2A & $0.26-0.31$ & $0.16-0.21$ & $36-42$ & $0.08-0.10$ & $22.0-24.6$ \\
\hline LBS $^{1}$ & 331-e2-11 & $0.12-0.24$ & $0.17-0.37$ & $35.6-45.6$ & $0-0.07$ & $\mathrm{X}$ \\
LBS $^{1}$ & 216a & $0.26-0.36$ & $0.08-0.12$ & $34-39$ & N/A & $\mathrm{X}$ \\
\hline GAG $^{2}$ & HJ-58C & $0.28-0.29$ & $0.10-0.11$ & 32 & N/A & $\mathrm{X}$ \\
GAG $^{1}$ & 10-AI-76 & $0.49-0.68$ & $0.21-0.40$ & $38.6-49.6$ & $0.09-0.31$ & $\mathrm{X}$ \\
GAG & HJ-57-C2 & $0.13-0.26$ & $0.01-0.09$ & $5.9-19.6$ & N/A & $4.5-5.0$ \\
\hline
\end{tabular}

${ }^{1}$ Hindemith et al. (2017) ${ }^{2}$ Strowbridge (2006)

$\mathrm{X}$ : none in sample; N/A: Not measured; $\mathrm{x}(\mathrm{Fe})=\mathrm{Fe} /(\mathrm{Mg}+\mathrm{Fe})$; p.f.u: Per formula unit $\mathrm{Ti}$ and $\mathrm{Al}^{\mathrm{VI}}$ are on the basis of 11 oxygen 
Table 4. Compositional ranges of feldspars.

\begin{tabular}{llcccccc}
\multicolumn{1}{c}{} & \multicolumn{3}{c}{ Plagioclase } & \multicolumn{3}{c}{ K-feldspar } \\
\hline Location & Sample & $\mathrm{Ab}$ & $\mathrm{An}$ & $\mathrm{Or}$ & $\mathrm{Ab}$ & $\mathrm{An}$ & $\mathrm{Or}$ \\
\hline PLV-LM & 10-AI-58-3B1 & $71.9-73.9$ & $25.3-27.2$ & $0.77-1.11$ & $14.1-17.9$ & $0.18-0.67$ & $81.5-85.7$ \\
PLV-LM & 10-AI-20A & $75.8-83.2$ & $16.0-22.7$ & $0.72-1.57$ & $10.8-15.9$ & $0-2.5$ & $83.1-86.3$ \\
PLV-LM & $10-\mathrm{AI}-58-2 \mathrm{~A}$ & $70.4-69.5$ & $28.7-29.5$ & $0.91-1.36$ & $8.9-14.9$ & $0.28-0.93$ & $83.4-90.3$ \\
\hline LBS $^{1}$ & $331-\mathrm{e} 2-11$ & $78.9-90.3$ & $8.4-20.6$ & $0.6-1.4$ & $7.9-21.3$ & $0.2-0.6$ & $78.4-91.2$ \\
LBS $^{1}$ & 216a & $73-94$ & $13-26$ & N/A & N/A & N/A & N/A \\
\hline GAG $^{2}$ & HJ-58C & 78 & $20-21$ & $1-2$ & $8.7-18.8$ & $0.01-1.8$ & $79.4-91.1$ \\
GAG $^{1}$ & $10-A I-76$ & $73.3-76.3$ & $22.7-26.9$ & $1-1.7$ & $8.4-19.0$ & $0.2-0.7$ & $76.3-92.1$ \\
GAG & HJ-57-C2 & $\mathrm{X}$ & $\mathrm{X}$ & $\mathrm{X}$ & $9.7-10.4$ & $0.32-0.36$ & $88.6-89.8$ \\
\hline
\end{tabular}

${ }^{1}$ Hindemith et al. (2017) ${ }^{2}$ Strowbridge (2006)

$X$ : none in sample; N/A: Not measured;

Ab: Albite; An: Anorthite; Or: Orthoclase 
Table 5. Bulk compositions.

Oxides $(\mathrm{mol} \%)$

\begin{tabular}{|c|c|c|c|c|c|c|c|c|c|c|c|c|c|c|c|}
\hline & $\mathrm{SiO}_{2}$ & $\mathrm{Al}_{2} \mathrm{O}_{3}$ & $\mathrm{MgO}$ & $\mathrm{FeO}$ & $\mathrm{MnO}$ & $\mathrm{CaO}$ & $\mathrm{Na}_{2} \mathrm{O}$ & $\mathrm{K}_{2} \mathrm{O}$ & $\mathrm{TiO}_{2}$ & $\mathrm{H} 2 \mathrm{O}$ & sum & $\mathrm{x}(\mathrm{Fe})$ & $x(\mathrm{Na})$ & $\mathrm{x}(\mathrm{K})$ & $\mathrm{x}(\mathrm{Ca})$ \\
\hline \multicolumn{16}{|l|}{ PLV } \\
\hline $10-A I-20-A$ & 73.75 & 10.25 & 3.8 & 4.56 & 0.09 & 0.67 & 1.49 & 3.52 & 0.3 & 1.58 & 100 & 0.55 & 0.26 & 0.62 & 0.12 \\
\hline 10-AI-58-3B1 & 52.57 & 21.25 & 8.55 & 8.53 & 0.06 & 0.36 & 0.44 & 3.02 & 1.46 & 3.77 & 100 & 0.50 & 0.12 & 0.79 & 0.09 \\
\hline $10-\mathrm{AI}-58-2 \mathrm{~A}$ & 83.64 & 6.35 & 2.75 & 3.03 & 0.03 & 1.63 & 0.26 & 1.02 & 0.17 & 1.13 & 100 & 0.52 & 0.09 & 0.35 & 0.56 \\
\hline \multicolumn{16}{|l|}{ LBS } \\
\hline $331-\mathrm{e} 2-11$ & 67.09 & 10.87 & 4.69 & 4.94 & 0.05 & 1.11 & 2.73 & 5.21 & 0.89 & 2.41 & 100 & 0.51 & 0.30 & 0.58 & 0.12 \\
\hline $216 a$ & 73.97 & 9.38 & 3.94 & 4.91 & 0.00 & 1.36 & 1.75 & 3.60 & 0.63 & 0.46 & 100 & 0.55 & 0.26 & 0.54 & 0.20 \\
\hline \multicolumn{16}{|l|}{ GAG } \\
\hline HJ-58C & 72.17 & 9.93 & 4.25 & 6.49 & 0.08 & 1.62 & 2.81 & 1.59 & 0.29 & 0.76 & 100 & 0.60 & 0.47 & 0.26 & 0.27 \\
\hline $10-A I-76$ & 74.94 & 9.99 & 1.89 & 3.20 & 0.14 & 1.28 & 2.57 & 5.03 & 0.36 & 0.61 & 100 & 0.63 & 0.29 & 0.57 & 0.14 \\
\hline $\mathrm{HJ}-57 \mathrm{c} 2$ & 88.54 & 6.54 & 1.72 & 0.61 & 0.03 & 0.01 & 0.18 & 1.41 & 0.34 & 0.62 & 100 & 0.26 & 0.11 & 0.88 & 0.00 \\
\hline \multicolumn{16}{|l|}{$\begin{array}{l}\text { Melt } \\
\text { reintegrated }\end{array}$} \\
\hline $10-A I-20-A$ & 71.87 & 9.82 & 3.08 & 3.77 & 0.00 & 0.66 & 1.85 & 3.45 & 0.24 & 5.25 & 100 & 0.55 & 0.31 & 0.58 & 0.11 \\
\hline 10-AI-58-3B1 & 53.96 & 19.58 & 7.52 & 7.54 & 0.00 & 0.41 & 0.78 & 3.05 & 1.28 & 5.69 & 100 & 0.50 & 0.18 & 0.72 & 0.10 \\
\hline $10-A I-76$ & 73.94 & 9.78 & 1.73 & 2.96 & 0.00 & 1.22 & 2.63 & 4.85 & 0.32 & 2.58 & 100 & 0.63 & 0.30 & 0.56 & 0.14 \\
\hline $331-e 2-11$ & 66.78 & 10.64 & 4.31 & 4.59 & 0.00 & 1.07 & 2.79 & 5.03 & 0.81 & 3.85 & 100 & 0.52 & 0.31 & 0.57 & 0.12 \\
\hline HJ-58C & 68.79 & 9.46 & 4.04 & 6.19 & 0.00 & 1.54 & 2.68 & 1.52 & 0.28 & 5.51 & 100 & 0.60 & 0.47 & 0.26 & 0.27 \\
\hline
\end{tabular}

$\mathrm{x}(\mathrm{Fe})=\mathrm{Fe} /(\mathrm{Fe}+\mathrm{Mg}) ; \mathrm{x}(\mathrm{Na})=\mathrm{Na} /(\mathrm{Na}+\mathrm{K}+\mathrm{Ca}) ; \mathrm{x}(\mathrm{K})=\mathrm{K} /(\mathrm{Na}+\mathrm{K}+\mathrm{Ca}) ; \mathrm{x}(\mathrm{Ca})=\mathrm{Ca} /(\mathrm{Na}+\mathrm{K}+\mathrm{Ca})$ 
Table 6. Mineral isopleths of samples and $P-T$ path coordinates.

\begin{tabular}{lcccccccc} 
& & \multicolumn{3}{c}{ Isopleths } & \multicolumn{3}{c}{$P-T$ path coordinates } \\
\hline Location & Sample & $\mathrm{x}(\mathrm{g})$ & $\mathrm{x}(\mathrm{bi})$ & $\mathrm{z}(\mathrm{g})$ & $T$ & Peak $P$ & $\begin{array}{c}T \text { at } \\
\text { solidus }\end{array}$ & $\begin{array}{c}P \text { at } \\
\text { solidus }\end{array}$ \\
\hline PLV & 10-AI-20A & $\mathbf{6 5}$ & 38 & $2.2-\mathbf{3 . 2}$ & 840 & $9-11$ & 820 & $6-7$ \\
PLV & 10-AI-58-3B1 & $\mathbf{6 4}$ & 41 & $2.6-\mathbf{2 . 9}$ & 865 & $8-11$ & 839 & 6.1 \\
PLV & $10-$ AI-58-2A & 67 & 42 & $2.9-3.1$ & $\mathrm{X}$ & $\mathrm{X}$ & 841 & 6.5 \\
\hline LBS & 331-e2-11 & 62 & 51 & $2.3-\mathbf{4 . 2}$ & 830 & $9-11$ & 825 & $6.5-8$ \\
LBS & $216 \mathrm{a}$ & 53 & 37 & $3-4$ & 875 & $8-11$ & 874 & 7.2 \\
\hline GAG & HJ-58C & $\mathbf{6 5}$ & 40 & $2.4-\mathbf{3 . 0}$ & 845 & $8-11$ & 835 & $6.5-8.5$ \\
GAG & $10-A I-76$ & 73 & 43 & $4.5-5.9$ & 840 & $8-11$ & 840 & $6-8.5$ \\
\hline
\end{tabular}

Isopleths used in determining the minimum peak - are highlighted in bold.

$\mathrm{X}$ : Could not be determined.

$\mathrm{x}(\mathrm{g})=\mathrm{Fe} /(\mathrm{Fe}+\mathrm{Ca}+\mathrm{Mg})$ in garnet; $\mathrm{z}(\mathrm{g})=\mathrm{Ca} /(\mathrm{Fe}+\mathrm{Ca}+\mathrm{Mg})$ in garnet; $\mathrm{x}(\mathrm{bi})=\mathrm{Fe} /(\mathrm{Fe}+\mathrm{Mg})$ in biotite 
Table 7. Mineral modes compared with the modes at the solidus of the phase equilibria diagram.

\begin{tabular}{lrrrrrrrrrrrr} 
& \multicolumn{1}{c}{ 10-AI-20A } & \multicolumn{1}{c}{ 10-AI-58-3B1 } & \multicolumn{2}{c}{ 331-e2-11 } & \multicolumn{2}{c}{ 216a } & \multicolumn{2}{c}{ HJ-58c } \\
\hline & TS mode & Solidus & TS mode & Solidus & TS mode & Solidus & TS mode & Solidus & TS mode & Solidus & TS mode & Solidus \\
\hline Garnet & 7.10 & 8.86 & 9.57 & 13.51 & 3.64 & 5.76 & 12.48 & 17.30 & 13.98 & 19.41 & 4.75 & 7.02 \\
Biotite & 12.20 & 13.91 & 34.84 & 31.95 & 19.01 & 21.76 & 4.09 & 4.31 & 6.75 & 7.77 & 5.20 & 5.50 \\
Sillimanite & 5.31 & 5.31 & 30.92 & 25.91 & 0.59 & 0.00 & 0.50 & 0.34 & 1.99 & 1.81 & 0.02 & 0.00 \\
Cordierite & 0.05 & 0.00 & 2.25 & 4.42 & 0.00 & 0.00 & 0.87 & 0.00 & 0.00 & 0.00 & 0.00 & 0.00 \\
Quartz & 36.57 & 36.86 & 12.53 & 12.04 & 14.88 & 15.94 & 32.12 & 32.15 & 35.08 & 34.00 & 23.26 & 24.26 \\
Feldspars & 38.75 & 34.99 & 9.81 & 11.47 & 61.50 & 56.16 & 49.49 & 45.19 & 41.83 & 37.00 & 66.35 & 62.63 \\
\hline
\end{tabular}

TS mode: Mineral mode in thin section

Solidus: Mineral mode where the $P-T$ path crosses the solidus 
729 FIGURE CAPTIONS

730 Fig. 1. Generalized map of the Manicouagan and Lac du Milieu areas showing the

731 locations of the samples. Inset: location of the study area in the Grenville Province

732 (Modified after Indares and Moukhsil, 2013).

733 Fig. 2. SEM-MLA mineral maps for thin sections (46mm length) of aluminous gneisses

734 from the PLV, LBS and GAG. The maps were produced by Letourneau $(2011 ; 2 \mathrm{a}-2 \mathrm{c})$;

735 Hindemith et al., 2017; 2d, 2g); Lasalle and Indares (2014; 2e) this study (2f, 2h). Sericite

736 is derived from alteration of feldspars.

737 Fig. 3. Photomicrographs showing characteristic microstructures: (a) polyminerallic

738 inclusion in garnet (10-AI-58-3B1, XP) (b) biotite-quartz symplectites (10-AI-20a, PPL);

739 (c) interstitial cordierite in the matrix (10-AI-58-2a, PPL); (d) cordierite corroding: (i)

740 garnet and (ii) sillimanite; cordierite pseudomorphing sillimanite prisms (10-AI-58-3B1,

741 PPL); (e) rounded quartz with thin rims of feldspar in the matrix (331-E2-11, XP); (f)

742 polyminerallic inclusions in garnet with thin rims of feldspar (331-E2-11, quartz plate);

743 (g) aluminous nodule (10-AI-76, PPL); (h) garnet and cordierite relationship (HJ-57-C2,

744 PPL). PPL: Plane polarized light, XP: Cross polars. Mineral abbreviations: garnet (g);

745 biotite (bi); sillimanite (sill); K-feldspar (ksp); quartz (q); spinel (sp); cordierite (crd).

746 Fig. 4. Average mineral composition parameters for: garnet on (a) Alm-Prp-Grs+And

747 and (b) Alm-Prp-Sps ternary diagrams, (c) biotite in terms of Ti (p.f.u = per formula

748 unit) vs. $\mathrm{x}(\mathrm{Fe})=\mathrm{Fe} /(\mathrm{Fe}+\mathrm{Mg})$ and $(\mathrm{d})$ plagioclase on a $\mathrm{Na}-\mathrm{Ca}-\mathrm{K}$ ternary diagram.

749 Fig. 5. Bulk compositions plotted on an AFM diagram. 
750 Fig. 6. $P-T$ pseudosections showing the general topologies and relevant isomodes in 751 Field I (red box) for (a) 10-AI-20A, and (b) 10-AI-58-3B1 from the PLV-LM, (c) 331752 e2-11 and (d) 216a from the LBS, and (e) HJ-58c and (f) 10-AI-76 the GAG. Mineral 753 abbreviations: garnet (g); biotite (bi); sillimanite (sill); K-feldspar (ksp); plagioclase (pl);

754 quartz (q); silicate melt (liq); rutile (ru); ilmenite (ilm); cordierite (cd); orthopyroxene 755 (opx); muscovite (mu). Phases in the top right box are stable throughout.

756 Fig. 7. $P-T$ pseudosections from Fig. 6 with a reduced range showing relevant isopleths 757 (as \%) and inferred $P-T$ paths. Phases in the top right box are stable throughout.

758 Fig. 8. Melt reintegrated $P-T$ pseudosections for selected samples. Phases in the top right 759 box are stable throughout.

760 Fig. 9. $P-T$ pseudosections for samples (a) 10-AI-58-2a and (b) HJ-57-C2, both of which 761 have interstitial cordierite at the thin section scale. 


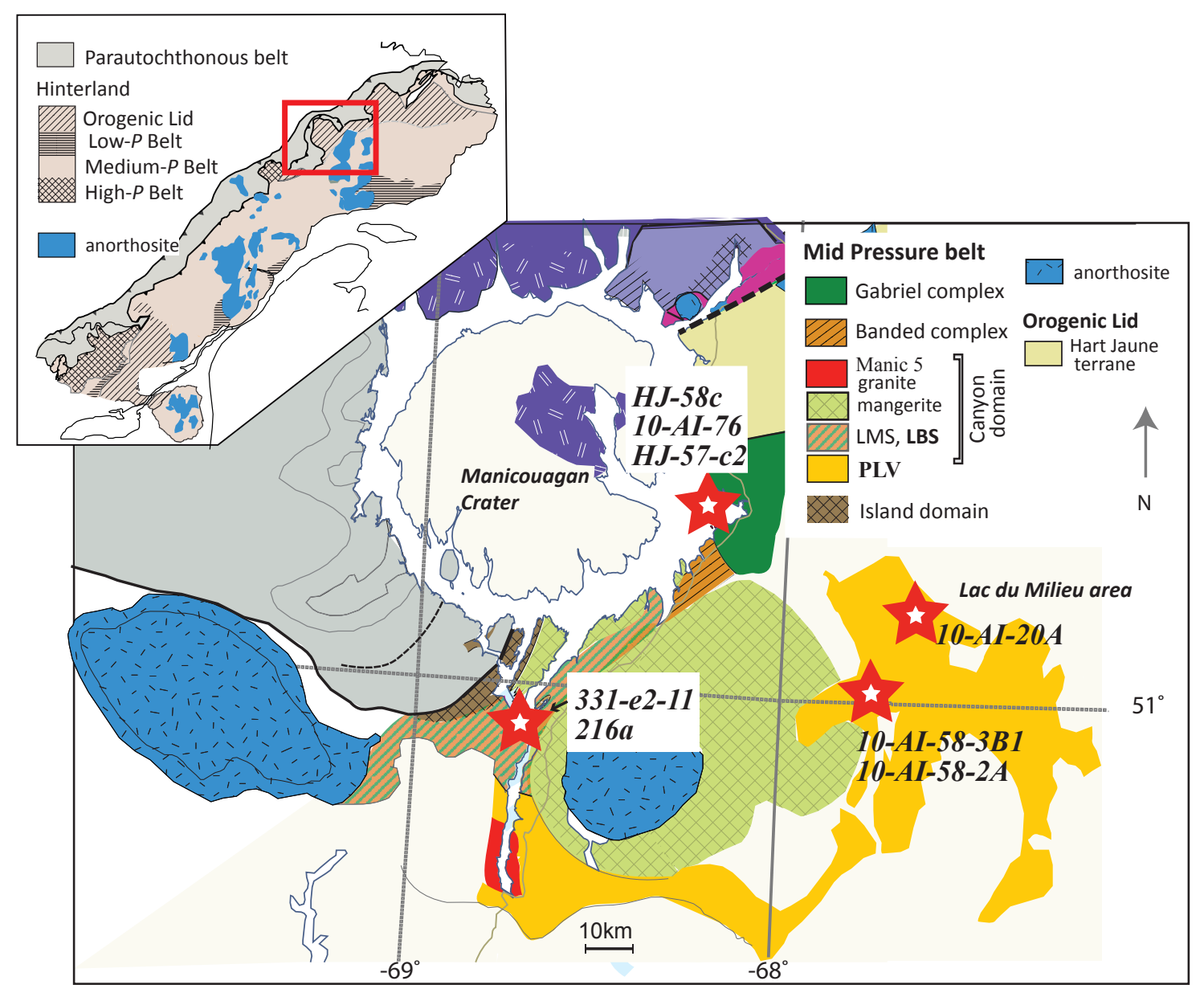

Figure 1 

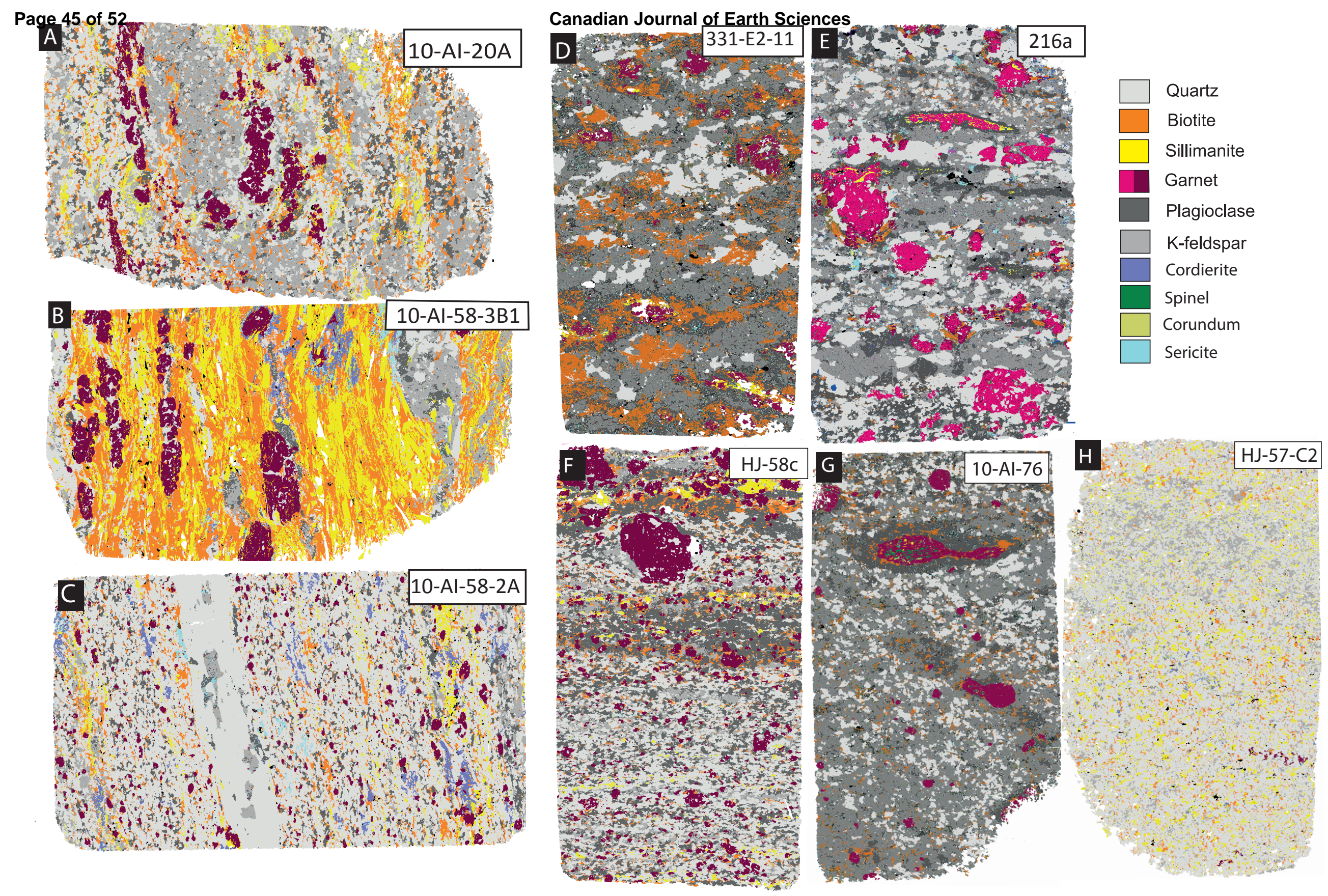

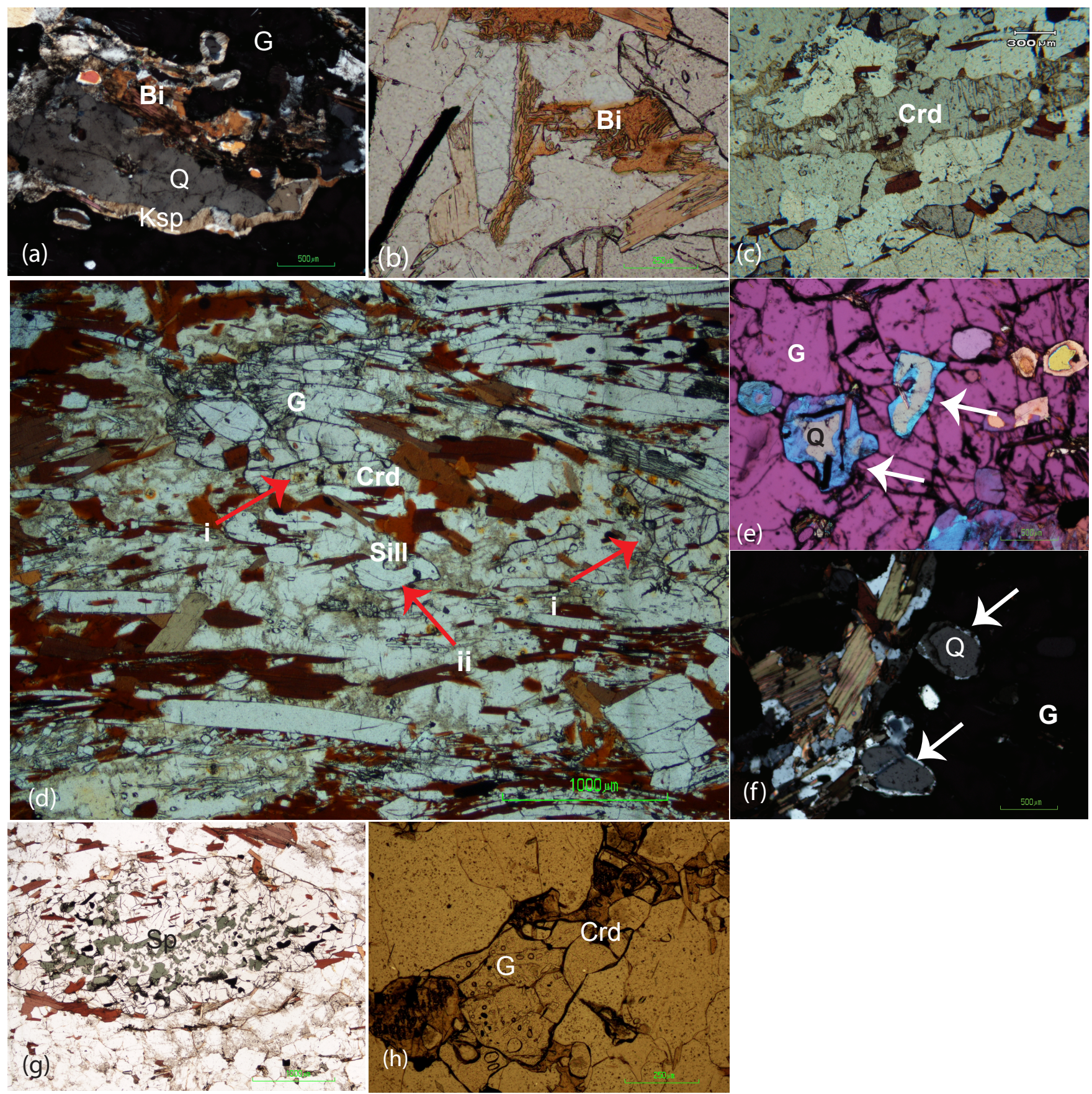


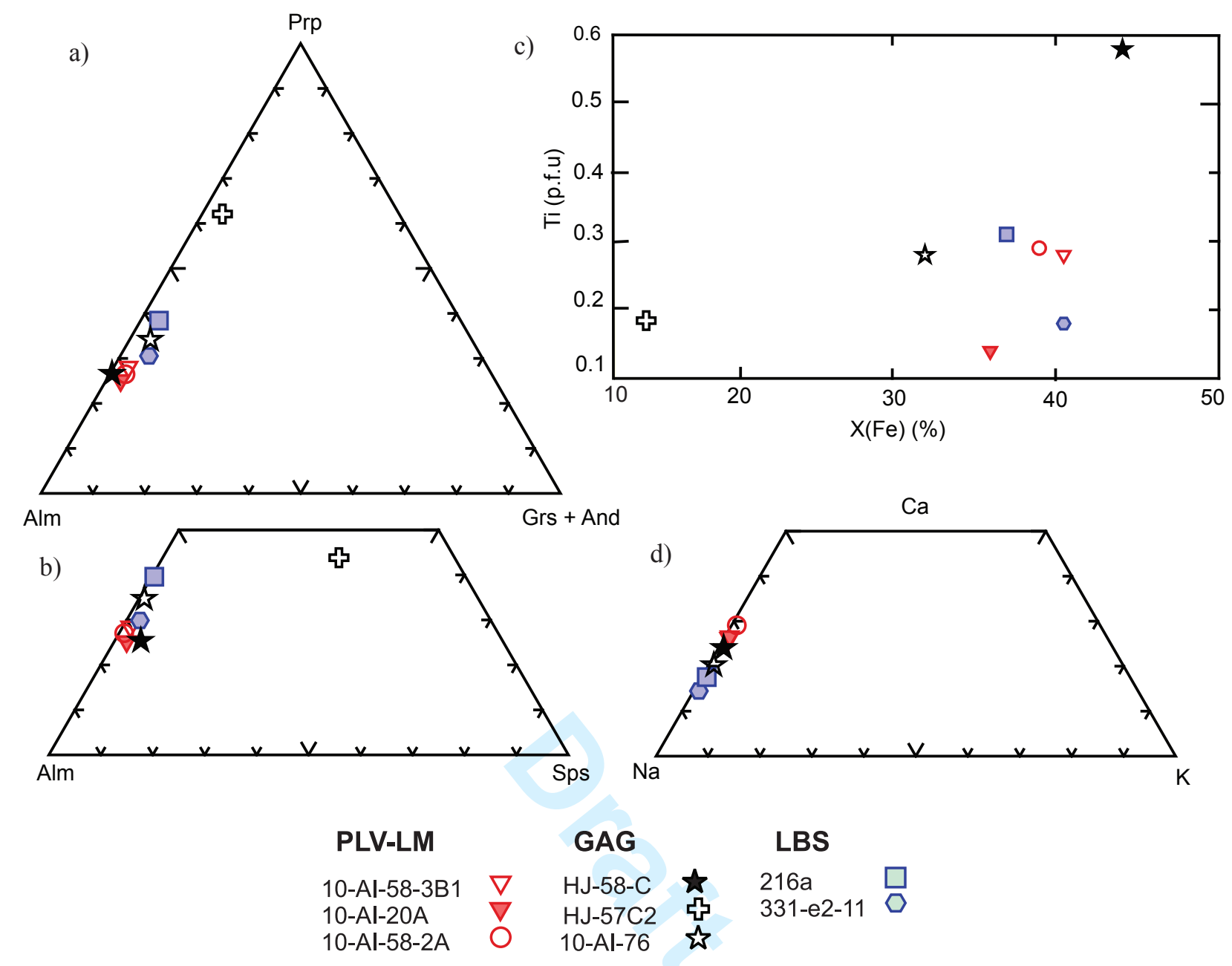

Figure 4 


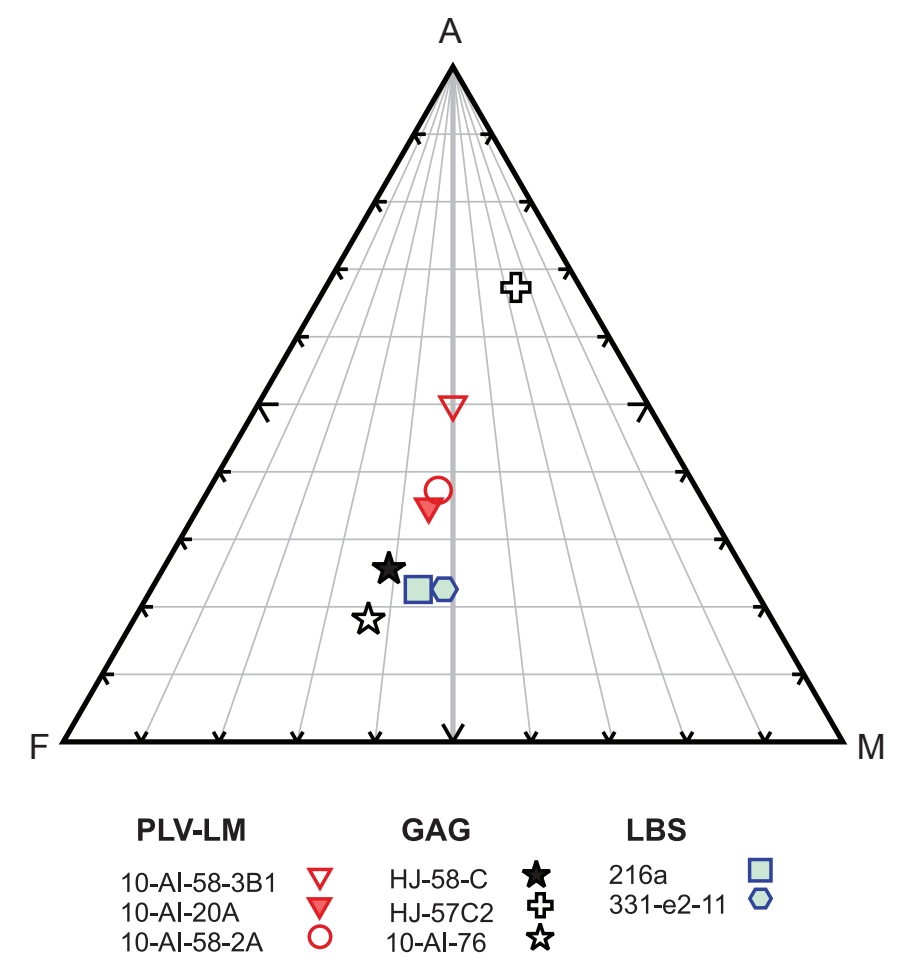

Figure 5 

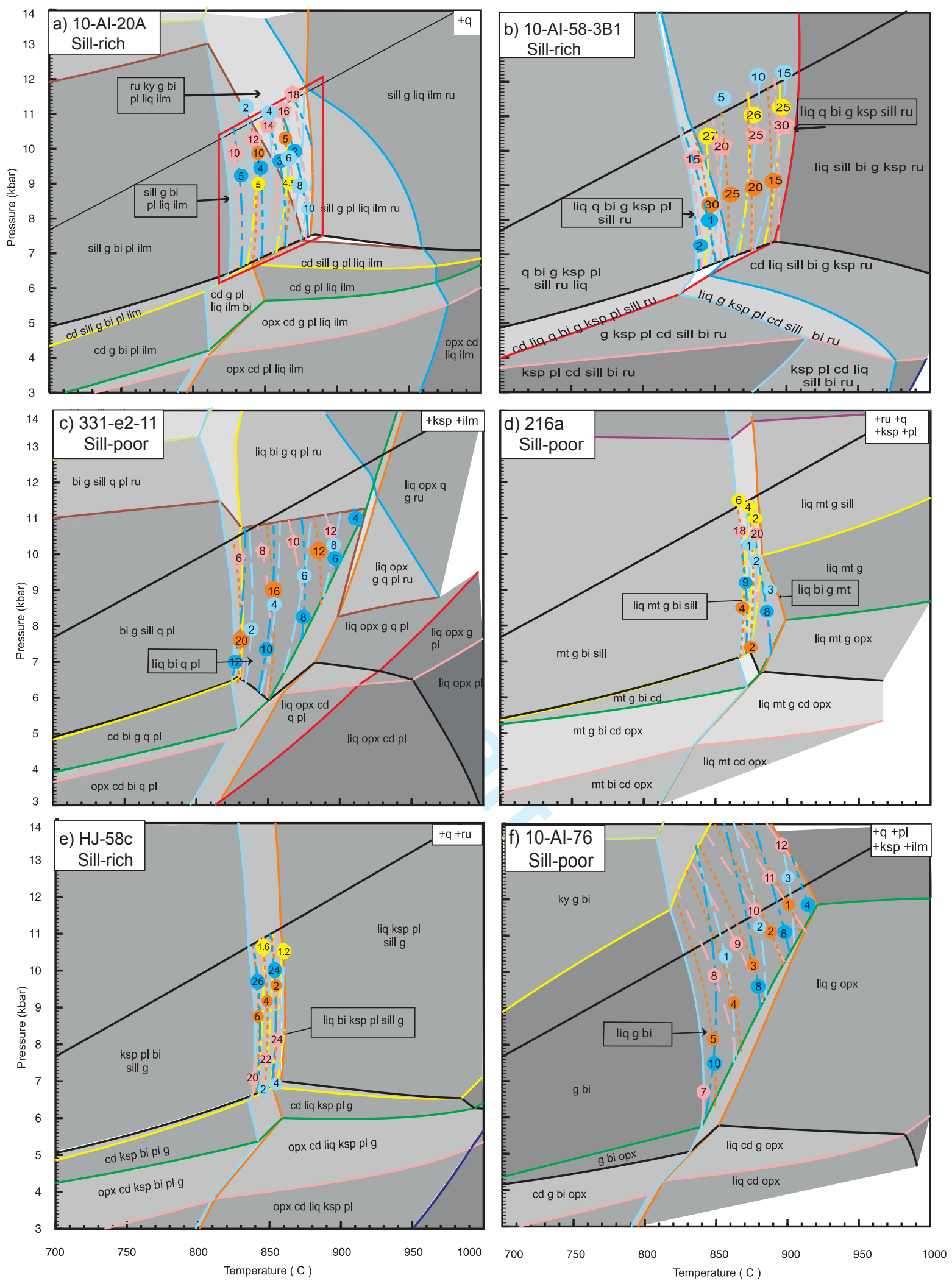

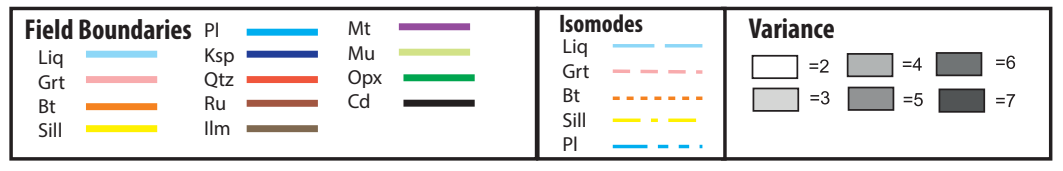

Figure 6 

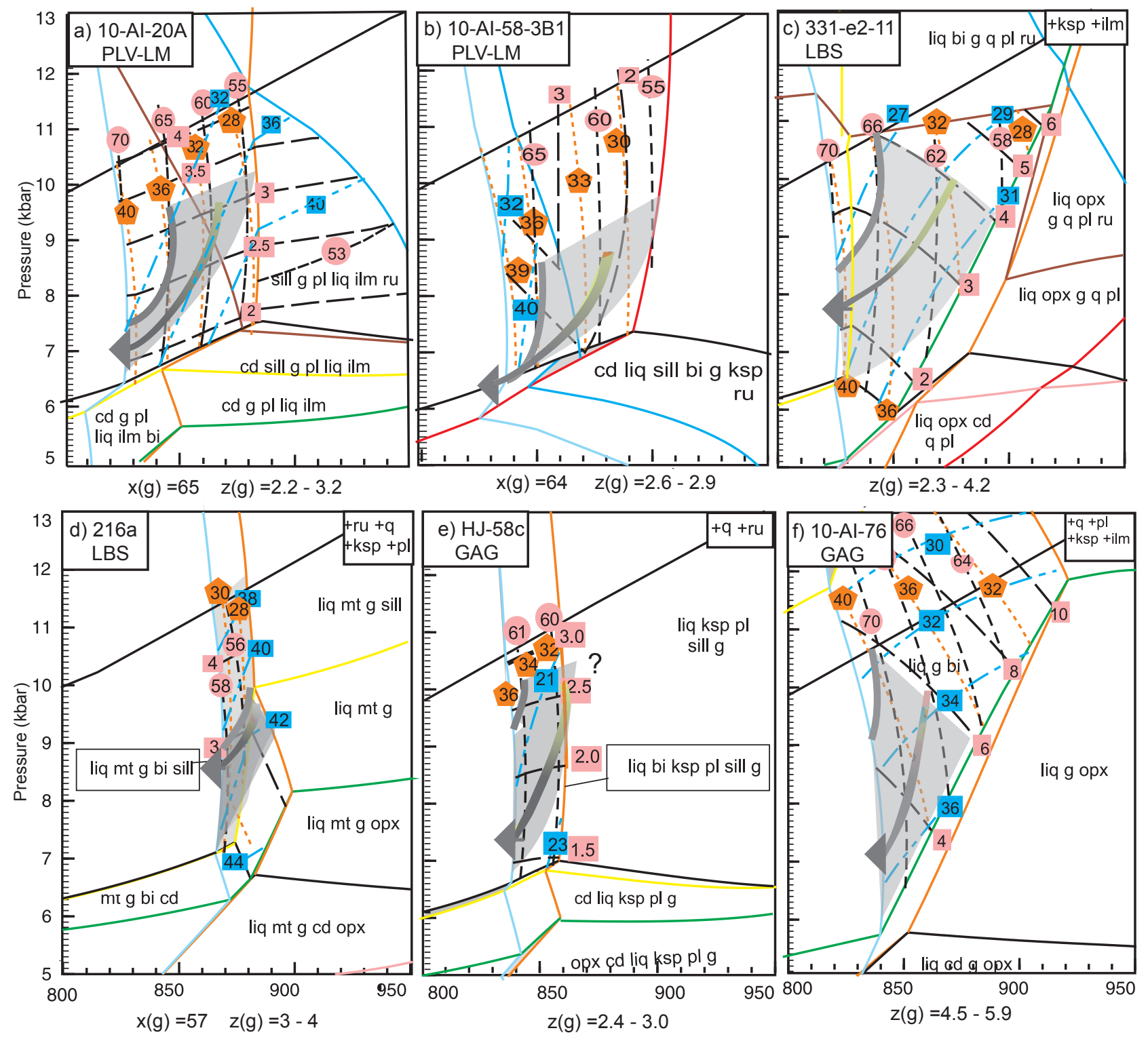

Temperature (C)

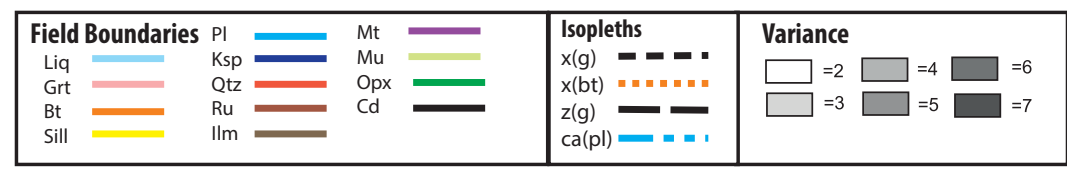

Figure 7 

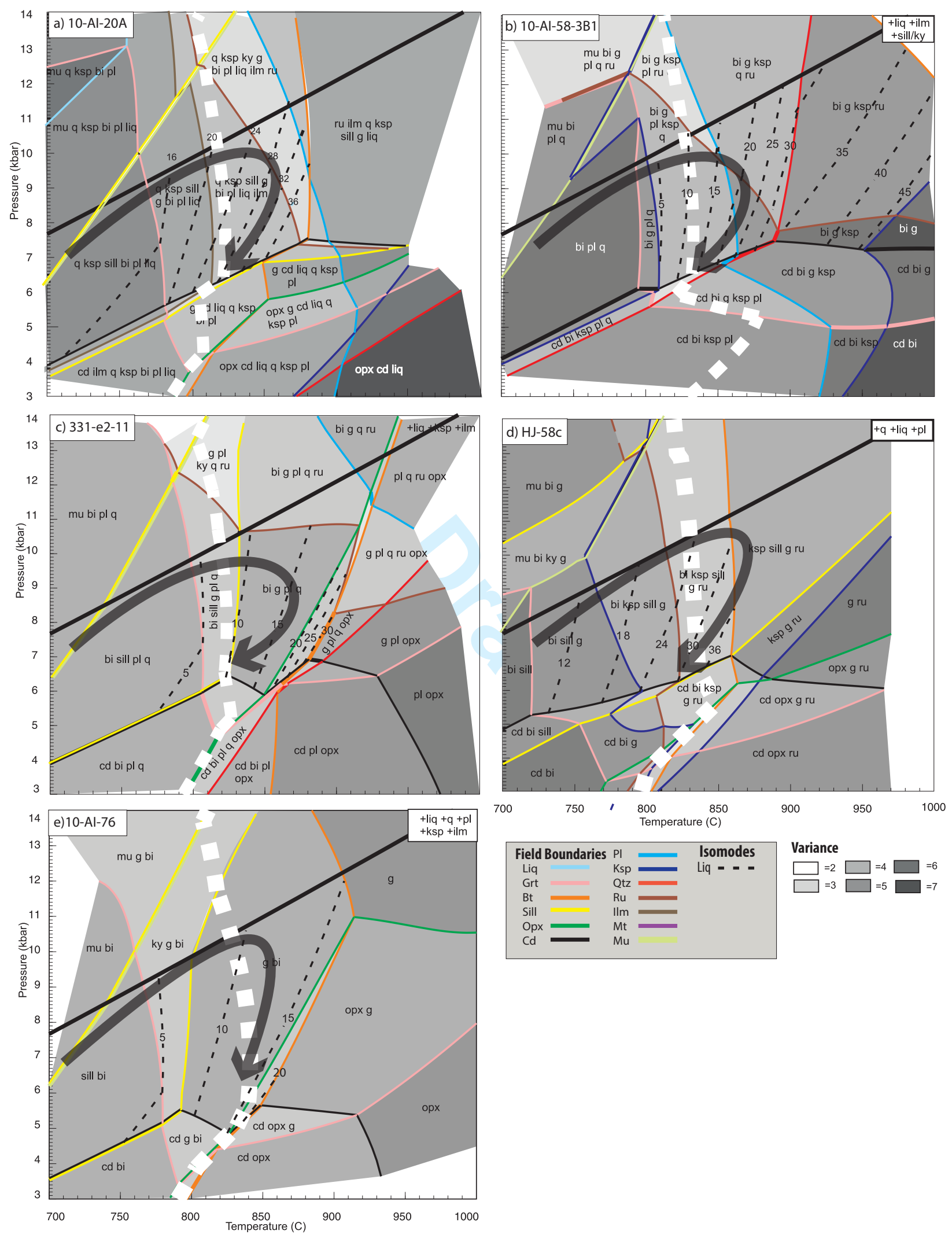

Figure 8 

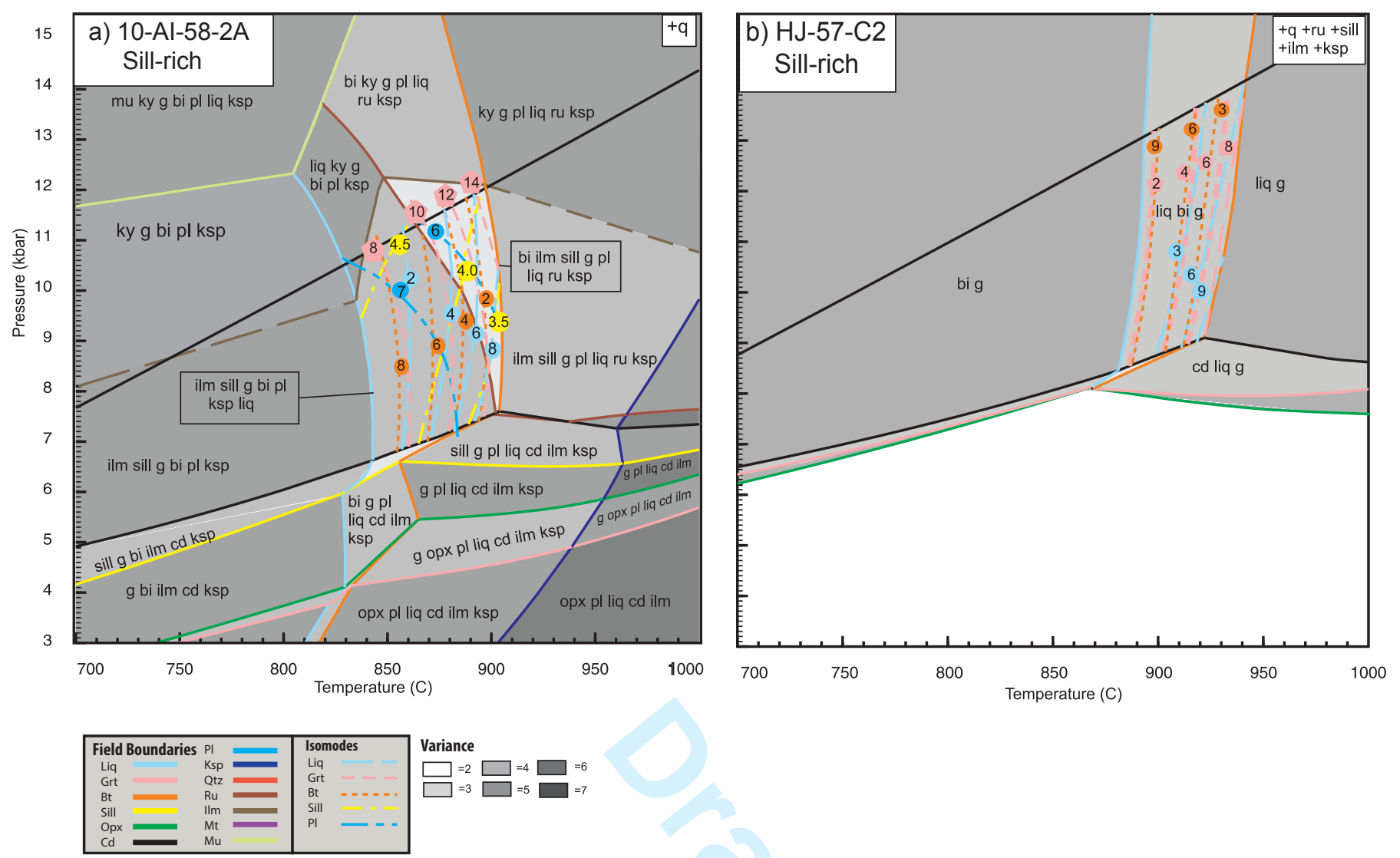

Figure 9 